The

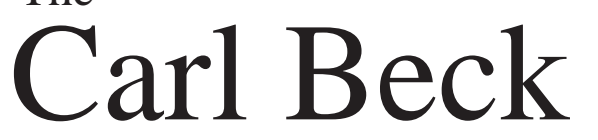

Papers

in Russian \&

East European Studies

Number 1408

Michael Melancon

Rethinking Russia's

February Revolution:

Anonymous Spontaneity or

Socialist Agency? 
The

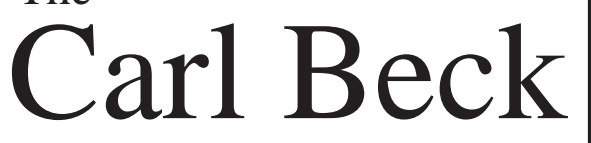

Papers

in Russian \&

East European Studies

Number 1408

Michael Melancon

Rethinking Russia's

February Revolution:

Anonymous Spontaneity or

Socialist Agency? 
Michael Melancon received his Ph.D. from Indiana University in 1984. He is Associate Professor of History at Auburn University in Alabama. His articles and book pertain to the history of the revolutionary movements and the revolutions, with special emphasis on the SRs and Left SRs. He is completing a book manuscript about the Lena Goldfields massacre and societal responses to it.

No. 1408, June 2000.

(C) 2000 by The Center for Russian and East European Studies, a program of the University Center for International Studies, University of Pittsburgh

ISSN 0889-275X

The Carl Beck Papers

William Chase, Bob Donnorummo, Ronald H. Linden, Co-Editors Eileen O’Malley, Managing Editor

Submissions to The Carl Beck Papers are welcome. Manuscripts must be in English, double-spaced throughout, and between 40 and 90 pages in length. Acceptance is based on anonymous review. Mail submissions to: Editor, The Carl Beck Papers, Center for Russian and East European Studies, 4400 W. W. Posvar Hall, 230 South Bouquet Street, University of Pittsburgh, Pittsburgh, PA 15260. 
Six decades ago William Chamberlin wrote that "the collapse of the Romanov autocracy ... . was one of the most leaderless, spontaneous, anonymous revolutions of all times.... No one ... realized that the strikes and bread riots ... would culminate in the mutiny of the garrison and the overthrow of the government." ${ }^{1}$ The kernel of truth in this description, that no one knew for sure that the strikes of 23 February marked the beginning of the end of tsarism, has ever since mesmerized historiography of the revolution, leading to grave misapprehensions of what occurred and why. My 1990 study of the revolutionary movement during World War I and in the February Revolution painted an alternative picture in which socialist agency looms large in the onset and carrying out of tsarism's overthrow. ${ }^{2}$ New evidence about the February Revolution further strengthens my original arguments. This study's twofold purpose is to orient readers in the complicated events that preceded and accompanied the fall of the old regime and, with the use of new archival materials and analysis, renew the case for reinterpreting Russia's February Revolution. ${ }^{3}$

While striving to fix in our minds the central role of the revolutionaries, virtual outcasts in the historiography of the February Revolution, I will pay special attention to the Socialist-Revolutionaries (SRs). ${ }^{4}$ This is not to stress the significance of any single party. Indeed, the evidence adduced here again highlights coordination among the revolutionaries, whose efforts, despite some differences in outlook, became all the more formidable. ${ }^{5}$ Nor, by the way, does this study portray revolutionaries issuing marching orders to worker-soldier minions.

\section{Historiographical Variations on a Theme}

Before examining detailed information about the overthrow of tsarism, let us briefly review the principal interpretative tendencies, beginning with Soviet variants and proceeding to Western ones. As noted by close students of Soviet historiography, J. D. White and David Longley, early Soviet accounts portrayed the February Revolution as spontaneous. White believes that Soviet historians of the 1920 s adhered to this view because the presence of only a few Bolshevik leaders in the capital during February 1917 imposed limits on the party's involvement. ${ }^{6}$ Perhaps the Petrograd Bolsheviks' relative inaction within the revolutionary movement of early 1917 also contributed to this interpretation.

Around 1930 Soviet historiography entered the realm of myth-making as regards the 1917 revolutions. Historical treatment of the February Revolution and all other aspects of revolutionary Russia served to legitimize the Bolsheviks' coming to power and thereby undergird the post-October "triumphal march of soviet power," myth building upon myth. Trotsky's famous attribution to the Bolsheviks of ground- 
breaking work in preparing the mass elements of society for the revolution fit neatly into this allegory since it represented a cosmic exaggeration of pre-1917 Bolshevik influence. From the early 1930s until the end of the Soviet Union, Bolshevik activism and agency occupied center stage in a vast number of Soviet studies of the February Revolution. ${ }^{7}$ Partial exceptions were the studies of Burdzhalov, Leiberov, and a few others, which somewhat de-emphasized Bolshevik activism, noted the involvement of other parties, and implied worker agency in the revolution. ${ }^{8}$ Although these "revisionist" studies still exaggerated the independent Bolshevik role, they pointed toward more objective analysis.

As regards Western historiography, it essentially begins with Chamberlin's famous statement quoted above. Unfortunately, it all but ends there as well. Let us first examine the few exceptions that prove the rule. In an otherwise informative account, George Katkov argued that German subventions of the Bolsheviks somehow wrought the overthrow of the tsarist regime. ${ }^{9}$ That the German government channeled funds to antiwar Russian socialists (Bolsheviks and SRs) is beyond question. Few will agree, however, that this produced the February Revolution. Katkov's approach represents a vast miscalculation of Bolshevik capabilities, funded or unfunded and, in fact, of their intentions. Of all the socialist groups, they were the least prepared psychologically and organizationally for the revolution, the point Burdzhalov attempted to make in his famous 1956 article with its focus on post-February Bolshevik ineffectiveness.

Tsuyoshi Hasegawa's highly regarded study of the February Revolution also calls into question the spontaneity theory but in a way that leaves it intact. Hasegawa argues that mid-level party activists played a role at all stages, both in calling the initial strikes and in leading the accompanying demonstrations that culminated in confrontation and revolution. Of the parties, he takes the Bolsheviks most seriously, finding them more organized and militant than the others. Hasegawa dismisses the socialist leadership as a group of intellectuals, a kind of debating society, remote from laborers and unable to play a role in mass action. Most recently of all, J. D. White displays scepticism toward the spontaneity theory without providing his own analytical alternative. His narrative focus on worker action and to some extent on subaltern Bolshevik groups such as the Vyborg Committee implies joint worker-Bolshevik agency. ${ }^{10}$ Their shared emphasis on mid- or lower-level, mostly Bolshevik, activism places Hasegawa, White, Burdzhalov, and Leiberov in similar analytical camps.

Of recent Western interpretations, my 1990 study is least consonant with the spontaneity theory. I argued that no detailed plan existed or could have existed for a revolution beginning with strikes on 23 February and culminating in a soldiers' revolt on 27 February. Instead, an array of socialist organizations directly intervened 
in every step of the revolution in a way that renders irrelevant our usual understanding of "spontaneity." With its focus on several socialist groups instead of on the Bolsheviks, this interpretation has failed to attract many adherents or, for that matter, inspire much commentary. Likewise, the Burdzhalov-Leiberov and Hasegawa-White approaches, variants of the spontaneity theory with little room for conscious socialist agency, do not suffice to shake the prevailing interpretation.

A telling measure of where the field stands on this question are portrayals in general histories written by prominent, knowledgeable persons, who do not, however, focus their research on the February Revolution. For example, in The Russian Revolution, first published in the early 1980s, Sheila Fitzpatrick writes that "in the last week of February, bread shortages, strikes, lock-outs and finally a demonstration in honor of International Women's Day by female workers of the Vyborg District brought a crowd on to the streets of Petrograd that the authorities could not disperse." "The autocracy collapsed," she claims, "in the face of popular demonstrations and the withdrawal of elite support." 11 Richard Pipes provides a quite similar picture in his The Russian Revolution, published a decade later. He describes the vagaries of weather and food supply and notes strikes and demonstrations on International Women's Day, organized by socialists, for bread and women's rights, after which "the situation in Petrograd deteriorated." The strikes widened with the help of "catalytic agents," that is, radical intellectuals, who by the twenty-fifth "sensed a revolution in the making." After this faint bow to socialist agency, Pipes quickly retreats to more familiar terrain. The "early disorders in Petrograd,” he assures us, “. . . were essentially a golodnyi bunt, a hunger strike,” and supports this by quoting a 26 February provocateur's report: "the movement broke out spontaneously, without preparation and exclusively on the basis of the supply crisis." 12

In his new book, The Soviet Experiment, Ronald Suny comments that "no one suspected in February 1917 that they were about to experience events that would alter world history." With some Social Democratic (SD) preparation, women workers of the Vyborg District decided to strike and demonstrate for International Women's' Day. "Even Bolshevik activists," continues Suny, "were at first wary.” The workers' rebellion of later days finally achieved the status of revolution when "suddenly, unpredictably some members of the ... Pavlovskii Guards Regiment mutinied and joined the crowds." ${ }^{13}$ In an otherwise quite innovative history of the 1917-1921 era, Christopher Read agrees that "when the February demonstrations began no one seriously believed that the final crisis of the autocracy was at hand.” Food shortages propelled "tens of thousands of working people ... into the streets [while] the members of the main socialist parties were busy printing leaflets, sending out speakers and doing whatever they could to articulate the workers' demands." Shaping actual 
events, according to Read, remained beyond the organizational capabilities of the socialists, who "at most ... were midwives of worker protest." ${ }^{14}$ Notice how closely these accounts adhere to Chamberlin's early description, the Ur-text of the February Revolution. The reigning traditional version portrays the socialists as utterly oblivious to the situation, which alters somewhat only after hunger impels working women and men into the streets for several days running. We hold fast to the theory of the February Revolution's essential spontaneity as though to a rock in stormy seas.

\section{Memoirists' Disputatious Voices}

Commentators have often noted participants' alleged surprise at the revolution's occurrence. The Left SR Mstislavskii wrote that the February Revolution caught the revolutionaries, like the vestal virgins, fast asleep. Just a few days after the event, the Right SR Zenzinov commented, "The revolution was a great and joyous surprise for us revolutionaries, who had worked for it and always expected it." The Bolshevik activist Kaiurov wrote that "no one even thought of the imminent possibility of revolution.” The Left Menshevik Sukhanov felt that none of the parties were "prepared for the great overthrow." His party comrade Ermanskii later remarked that viewing the 23 February demonstrations "as a precursor to powerful events was something that at the time really did not enter my head." ${ }^{15}$ An impressive unanimity seems to prevail. Yet, did not the revolutionaries protest too much? Were they really so otiose? Analysis of some of their statements casts doubt on how we have interpreted them. Was it not obligatory for Mstislavskii, as a Communist in the Soviet Union, to indicate that his (then) SR party was sleeping, which might even imply that some "other" party had been more alert? As regards Zenzinov's comment, we might well focus upon "worked for" and "expected" rather than on "surprise," although the revolution's success was a great shock, a signal turning point, a caesura between old and new. The sense of Kaiurov's statement is contradicted elsewhere in his own text, when he recalled the population's "powerfully stimulated mood" just prior to the February disturbances. "We could feel the storm coming," he continued, "but where it would go no one could determine." Ermanskii's chaste recollection that revolution "really did not enter [his] head" founders on his own preceding remarks about how his and other revolutionary groups issued militant publications that promoted International Women's Day strikes and helped transform them into an uprising. ${ }^{16}$

Regardless, ample quotations from these and other sources indicate a quite different story. Sukhanov recalled how a couple of days before 23 February the secretaries in the Ministry of Agriculture where he worked chatted about what seemed to be 
"the beginning of a revolution.” The Right Menshevik Denike, whom the February events found in Kazan, later insisted, "It is not true that no one expected revolution in Russia. By the end of 1916 it was a widespread expectation.” He recalled how just days before the tumult in the capital a friend remarked, "Well, we are headed for a revolution," to which Denike had agreed and, allegedly, predicted that "it would be a great catastrophe." The Bolshevik leader, Shliapnikov, emphasized the efforts of the joint socialist group to coordinate activities in the face of the remarkable crisis so as to "prevent the movement from dissipating itself." In the unpublished version of his memoirs, Zenzinov called this same group the "headquarters of the revolution" (glavnyi shtab revoliutsii) ${ }^{17}$ If Petrograd socialist leaders formed a group that met repeatedly in order to coordinate their activities in a crisis situation and if this group became the headquarters of the successful revolution that developed out of the crisis, then the socialists were hardly somnolent. Selections of memoirists' quotations just as numerous and valid as those we rely upon can craft a version of the February Revolution starkly at odds with the accepted one. Why favor one version over the other?

In view of the spontaneity theory's pre-1930 official status in the Soviet Union, the revolutionaries' memories of their alleged surprise and unpreparedness, especially when juxtaposed to countervailing information and analysis in the very same or other texts, achieve nullity in terms of historical value. We valorize politically obligatory remarks that fit (and shape) our prevailing interpretation and, in an act of historiographical prestidigitation, relegate to nonexistence all counterremarks and evaluations. In truth, the latter possess enhanced credibility since they incurred potential risks. Of the former, the less said ...

This contrived war of claims and counterclaims, buttressed with helpful quotations, proves nothing about the February Revolution. Only examination of a wide range of evidence establishes what happened. We should, however, have been more cautious about extracting the revolutionaries from the revolution, especially, of all places, in Russia. We should long ago have examined for basic verisimilitude (and rejected as implausible, indeed risible) revolutionaries' protestations of unaware innocence in light of their long-term aspirations and preoccupations, not to mention their verifiable actions before, during and after the early 1917 events.

\section{What the Authorities Said: A Preview}

By late fall of 1916 and early 1917 the tsarist secret police, the military command, and the Ministry of the Interior were acutely aware of the frightening intensity of the crisis that prevailed throughout Russian society, which they readily and 
often compared to 1905. Government officials spoke constantly of the imminence of revolution. ${ }^{18}$ The head of the Petrograd Province Gendarmes insisted that the "catastrophic hardships" suffered by society were "leading to the embitterment of the lower elements of society and ... to potentially rebellious demonstrations threatening the vital underpinnings of the state.” Authorities in Moscow, Kazan, Saratov, Simbirsk, and Tula sent in similar reports, as when the Moscow Okhrana wrote about "the state of extreme agitation of the working masses and social groups, ... [which] could create ... a very serious threat to official order and public security."

Not adherents of the spontaneity theory, the authorities also emphasized the involvement of revolutionaries, who hoped to utilize the societal crisis for the purpose of overthrowing the regime. Indeed what else would revolutionaries do? The Moscow Okhrana fretted about "the activities of revolutionary circles [in creating] a new onslaught of strikes and demonstrations." A police report from Petrograd expressed alarm at the growth "of the revolutionary underground ... by means of an influx of new members and the return from exile and from military service of old party members.” A high-level January 1917 report about the unrest in Russian society concluded that "the general move to the left of the population has aided the growth of the revolutionary organizations and the success of their propaganda.” The secret police noted not only the growth of individual organizations but their tendency to coordinate activities. The Bolsheviks, for example, had "decided to reach out to the Mezhraionka [a leftist SD group aimed at uniting the party] . . . and do not rule out ... the possibility of a bloc with the Narodniks [SRs]."

A late 1916 report on the strikes and demonstrations worried that "in view of the acute situation in the country and the heightened mood of the masses, things could take a turn for the worse, especially because of the unification [tendency] of the defeatist SDs and SRs." Reports noted a "cumulative demand to end the war" and the widespread opinion among the people that "we are on the eve of great events as in 1905." In the eyes of the authorities, the situation within the armed forces did not differ. After a late 1916 investigation, a horrified General Staff concluded that "revolutionary elements are setting about and possibly have already organized their forces [in the military] for an armed rising." In his first report of the new year, the prescient, half-mad Minister of the Interior Protopopov warned that "Russia was in the preparatory stages for a rising of unified revolutionary organizations.” Just prior to the outbreak of demonstrations on 23 February 1917, officials reported the intention of revolutionary groups to transform bread strikes into a revolutionary uprising. This should remind us that even bread strikes did not occur in a political vacuum.

Some commentators will doubtlessly characterize all this as governmental paranoia—a "revolutionary behind every bush." Perhaps this is the opinion of Read, 
who introduces into his text excerpts from some of the published government reports quoted above bereft of all references to the socialists. Since the revolution of 27 February 1917 immediately chose socialist leadership, elementary standards of evidentiary evaluation disallow so blithe a dismissal of the combined opinions of secret police, gendarmes, General Staff, and Interior Ministry.

\section{Prelude to Revolution: The Published Record}

Published evidence portrayed the general Petrograd revolutionary movement prior to February 1917 in the following manner. Several socialist organizations existed in the capital, as elsewhere, with at least the rudiments of top-, middle-, and lower-level structures. These organizations had ties with factories, garrison units, and educational establishments, as well as with one another. The socialist groups organized strikes and other antigovernmental actions on a regular basis; solely promoted the demonstrations for International Women's Day on 23 February, a socialist holiday; and directly involved themselves in all the disturbances of the following days. Before the February 1917 crisis, leaders of these organizations had formed a joint informational bureau with the goal of coordinating their activities. They met repeatedly just prior to and during the February crisis and for the last time as underground revolutionaries on the evening of 26 February.

The next day some of them-Duma deputies Kerensky, Chkheidze, and several others - issued a call to workers and soldiers to elect soviet deputies and send them to the Tauride Palace. Already that evening (27 February), the first small, tentative session of the Petrograd Soviet met under the guidance of its new executive committee which, with the gradual addition of some delegates from workers and soldiers, consisted of exactly the same socialist leaders who had met together on earlier days. To reiterate, the Duma socialists and underground activists who had met together on the previous evening and earlier occasions were now the de facto government of Russia. This circumstance alone raises sharp questions about the "leaderless, spontaneous and anonymous" nature of the revolution.

Published evidence about individual socialist parties, albeit incomplete, suggested in advance the picture now confirmed by archival materials to be analyzed presently. For example, during the months before the outbreak of the revolution, SR activities had the following character. The Soviet-era historian Shalaginova reported that SR propaganda from the fall of 1916 on, of which she examined a sizable quantity from many parts of the empire, took for granted that revolution was imminent and aimed at bringing it about. Illegal SR brochures from NizhniiNovgorod, Baku, Moscow, Petrograd, and other places called for the overthrow of 
tsarism and capitalism, an end to the war, sometimes called for the election of deputies to soviets and, more and more often, for an immediate armed uprising against the existing government. ${ }^{19}$ By the fall of 1916, SR activists and leaders had reached the conclusion that a revolution like that of 1905, based primarily on proletarian strikes and demonstrations, could not succeed at present because of the large number of soldiers in garrisons stationed around the country; only a revolution based upon the joint activities of the workers and soldiers could have the desired results. Consequently, the SRs, more than the Social Democrats, focused on propagandizing and organizing soldiers. At an early January 1917 meeting of underground SR leaders in the capital, the Left SR Aleksandrovich worried that if the workers came out alone without arms, they would only be subjected to the bullet and the whip of the Cossack and the soldier. He described instead a new kind of revolution of the armed worker and soldier masses. ${ }^{20}$ The police also reported radical revolutionary sentiment among SR student groups. ${ }^{21}$ Analogous, although not identical, information is available for the Social Democrats and anarchists.

Various memoirists recollected the growth and activism of SR worker circles and those of other parties in the factories of Petrograd (and elsewhere). Because of this, the rudiments of a citywide organization were gradually coming into place for the SRs. The Mezhraionka, the Bolsheviks, the Left Mensheviks, and the Right Mensheviks all had organizations. SR-oriented factory cells were uniting into district groups, and leaders were attempting to form a Petersburg Committee, although a high-level provocateur foiled the latter effort by betraying key activists who were promptly arrested. During the weeks just prior to the final strikes, SR proclamations distributed in Moscow and Petrograd openly predicted the victorious revolution. One such leaflet stated, "You, old warriors who had begun to doubt the victory of revolution, and you, young green soldiers, haven't you felt how the whole of enormous Russia has come alert? Surely you have heard the news that is spreading?” Another advised the population "to elect revolutionary organizations . . ., select your own deputies.... [and] disseminate propaganda throughout the proletariat, the peasantry and the armed forces."22

The prevailing spontaneity theory turns on socialist blindness to the gravity of the early 1917 crisis and, it follows, lack of substantive involvement. As Read describes the matter, "the decisive moments owed little to them." The foregoing information so ill fits this interpretation that one or the other must give way. Although Hasegawa has recently referred to "lively debates" about aspects of the February Revolution, this evidence, published a decade ago, has spurred no reevaluation of the February Revolution's central historiographical problematic, that is, its agency. ${ }^{23}$ 


\section{Prelude to Revolution: What the Archives Say}

New archival materials, with some emphasis on Petrograd, establish beyond doubt that from November 1916 on, all the socialists joined the direct struggle to overthrow the tsarist regime, not to be confused with the general revolutionary orientation of socialist programs. During mid-November 1916, the secret police reported on a series of meetings among the SRs, Bolsheviks, leftist and rightist Mensheviks, and the Mezhraiontsy (Mezhraionka members) aimed at forming an interparty informational bureau to "lead upcoming demonstrations." Some disagreements arose as to the authority of the bureau. The SRs and Mensheviks wished to invest it with the right to call strikes and demonstrations, whereas the Bolsheviks wanted party committees to have the final word. Regardless, the informational bureau achieved "complete unanimity" on its intention to "pursue the struggle against the government.” Numerous nonparty, SD, and SR factory collectives were holding protest meetings. After stormy October strikes, the workers seemed to calm down but by mid-November the police again characterized their mood as "alarming." 24

Besides their other reservations, the Bolsheviks, according to police reports, "did not feel the need at the moment to issue very definite resolutions [presumably in favor of direct steps toward revolution]," whereas the SR and Left Mensheviks not only favored such resolutions but wished to "send them directly to certain Duma deputies [doubtlessly Kerensky, Chkheidze, and other Duma socialists ].” The Right Mensheviks even suggested that entire socialist meetings report to the Duma with the resolutions in hand. ${ }^{25}$ Regardless, in forming the informational bureau the various parties aimed at promoting and coordinating strikes and demonstrations with the goal of overthrowing the government ("pursue the struggle against the government"). Reflective of this new resolve were the militant slogans of theWar-Industries Committees (WIC) worker groups which advocated a general strike and revolution, whereas previously the moderate Mensheviks and SRs of the worker groups had espoused a wartime accommodation with the tsarist regime. Left-wing socialism did not lag behind. A fall conference of Petrograd SR activists voted to "summon the laboring class to the struggle for a provisional revolutionary government and a democratic republic"; in the emigration, Lenin issued similar slogans. By late fall 1916 leftist SR and SD agitation was replete with direct calls for a "Revolutionary Provisional Government,” soviets, and an armed uprising, hardly common coin in quotidian socialist agitation. ${ }^{26}$

Of equal interest is the attempt of some socialists, especially the moderate Mensheviks, to link with the Duma in an evident strategy to carry out a Dumaoriented overthrow of the tsarist regime. Raymond Pearson claims that, as of the 
December 1916 suspension of the Duma, certain Progressist Duma leaders wished to reach out to the socialists with similar aims. ${ }^{27}$ According to the police reports, already by November the socialists had originated the idea of forging a potentially potent link between the mass socialist movement and Duma elements. In any case, from November 1916 on one version or another of revolution was on the immediate socialist agenda. Revolutionary leaders' and activists' subsequent actions must be judged in light of their concrete resolves that reflected actual experienced circumstances, rather than in the abstract, as though they had no take on events around them or, indeed, no surroundings.

Toward the end of 1916, the secret police noted a series of repressions of SR organizations in Petrograd, Irkutsk, Kharkov, Moscow, Kiev, Rostov-on-Don, Samara, Saratov, Baku, and Novgorod, and offered the opinion that these organizations had "not yet" formed a nationwide structure. During December the police carried out massive arrests of Petrograd Bolsheviks and during the last three months of the tsarist regime incessant, almost compulsive, arrests of anarchists as well. Not a few Mensheviks, especially those associated with the WIC Central Worker Group, also fell prey to arrest. ${ }^{28}$ Responding in part to increased repression and in part to the rising prospects for revolution, around the turn of the year a Petrograd SR conference voted to "enter a bloc with the SDs in the struggle for the formation of a new government [and] devote serious attention to propaganda in the armed forces and navy."29

During January, the secret police sent out inquiries to Finland, Vologda, and other places in a vain attempt to locate the SR Northern Military Organization, whose Novgorod membership had been arrested a year earlier. The police failed to ascertain that by early 1917 this SR military organization was operating in Arkhangelsk, Novgorod, Gatchina, Pskov, Petrograd, and other places behind the northern front, where it had become one of the chief suppliers of printed propaganda. ${ }^{30}$ One 1916 leaflet from the SR Northern Military Organization addressed to "Soldiers and Sailors" listed government atrocities and advised the men in uniform as follows: "It is time to put an end to the crimes, but remember once and for all that for that you need a powerful, solid organization. ... Create your own revolutionary organization, form company, battalion, ship and other committees, prepare for the struggle and wait for the call to resist the government ... And when the times comes ... we will raise the banner of struggle for the better future, for land and freedom." ${ }_{1}$

In early 1917 the secret police also sent out inquiries about the SR antiwar newspaper Klich (The Call) and finally got wind of its location in Kazan. Meanwhile, a December issue of the SR-Internationalist paper in Switzerland, Otkliki zhizni (Echoes of Life), reported the appearance of this leftist paper "from the Volga" in August 1916. In Geneva the SR Tsivin, a secret agent for the Germans and Aus- 
trians, showed copies of Klich to his bosses, an incident suggesting ties between antiwar leaders in the emigration and internal groups. ${ }^{32}$ While trying to eradicate SR activities, the police feverishly searched for the North-Baltic Social Democratic Organization, also the issuer of numerous antiwar leaflets. ${ }^{33}$ One has the impression from these police reports of time running out, as the revolutionary movement constantly expanded its output of incendiary proclamations to population segments ever more inclined to listen. Far from simply giving up or fading out of existence, until its very last hours the tsarist regime unrelentingly wielded the weapon of arrest against SRs, anarchists, and SDs. ${ }^{34}$

The authorities reported that on 9 January, the anniversary of Bloody Sunday, the Petrograd SRs and SDs had "attempted to organize the masses" and had even intended to use armed detachments, but heavy arrests had hindered their plans. By 20 January, they noted that "more and more the mood of the mass of workers is rising under the influence of uninterrupted and systematic . . revolutionary agitation.” On 4 February, the police claimed that "conscious workers are expecting a revolution in the near future" and that the tense atmosphere was now inducing the underground parties to consider the "real possibility of a revolution." A few days later, the authorities concluded that the "strivings of the extreme left groups to spark a hunger uprising cannot be considered ungrounded. . . . Massive spontaneous uprisings could occur in Petrograd because of the high costs and the heightened mood of the population," a situation that would be used, predicted the police, by the leftists groups. SRs, anarchists, and SDs were "all prepared to use extreme measures." Furthermore, concluded the police, the revolutionary parties were unifying their efforts and would even cooperate with the oppositionist Progressist Bloc in order to overthrow the government. A few reports held that the revolutionary leaders exaggerated society's disaffection and their own ability to utilize this mood. More often, internal reports verged on panic at what revolutionaries were doing. One early February document predicted that "events extraordinarily important and fraught with exceptional consequences for the Russian state are 'not far off' (ne za gorami)." 35 Even reports that claimed socialist exaggeration of societal disaffection and its usability disclose revolutionary intentionality. In view of these documents, who can doubt government officials' acute awareness of what was in the offing?

About the socialists, a 7 February police report explained that the SRs were indifferent as to occasion since they "did not presume to create the workers' movement independently, but when the strikes start they will hasten to join in so as to manifest themselves once again and inflict a blow against the government and the state structure against which they have been fighting." On the seventeenth, the police noted that the Trudovik Duma faction (which operated under Kerensky's leader- 
ship) had decided to "refrain from legislative activities in favor of using the Duma exclusively as an agitational tribune" in hopes that they could create a bloc among themselves, the Social Democrats, and the Progressists. In light of this tactic, they were maintaining close ties with underground SR circles so that they could more effectively agitate the general population and the army "for the purpose of preparing the ground for revolutionary demonstrations." 36

Mid-February reports claimed that the Petrograd SRs were convinced of "approaching powerful revolutionary events.” By January the Kharkov SRs, perhaps the most radical in the country, felt the time ripe for building nationwide party structures. They sent out agents to SR organizations in Samara, Nizhnii-Novgorod, Voronezh, Saratov, Petrograd, and Moscow with the goal of pooling efforts for the issuing of a national SR newspaper in Moscow. In early February, the police noted that the newspaper had not yet appeared because of the lack of "technical means" (that is, a printing press). Just then the Moscow SR organization obtained a high capacity printing press, presumably for the purpose of publishing the planned newspaper, that was the envy of all other socialist organizations in the city. ${ }^{37}$

Workers' memoirs collected for the History of the Party (Istpart) project also shed light from a different perspective, that is, from the bottom up. The recollections show the rapid growth of various party circles beginning during the early summer of $1915 .{ }^{38}$ A Putilov worker, Kapytianov, recalled attending his first interfactory meetings of two hundred or more SRs, Mensheviks, and Bolsheviks during May 1915. With the purpose of discussing worsening wartime conditions, he said, such meetings also took place in the Moskovskii, Nevskii, and Vyborg districts. A galvanizing event in the activities of workers' circles was the WIC campaign for worker groups. The campaign prompted numerous meetings and rather open debate about the war and other normally forbidden issues. Within many individual plants, arrests at the beginning of the war had disrupted prewar party cells and factory committees. Now the situation changed in the opposite direction.

Voronkov, an SR worker at the state-owned Arsenal munitions plant, recalled making the acquaintance of activists from the other parties during the mid-1915 WIC campaign, on the basis of which an informal group began to meet at his factory. The interparty group decided to promote a strike for the Bloody Sunday anniversary on 9 January 1916, with partial success, although the factory elders were opposed and much of the workforce supported, if anybody, the Constitutional Democrats. Its renewed strike activity increased the prestige of the Arsenal plant in revolutionary circles, since reputedly no workers had struck there since 1905. The SR group at the plant also began to hold regular meetings and contacted the Vyborg District SR organization, although this immediately aroused the attention of spies. 
One of the chief debate topics for the Arsenal factory committee was whether or not to subject itself to the moderate socialist local WIC worker group. The SRs and Bolsheviks argued against the Mensheviks on this point, with the result that the group declared itself independent of the WIC worker group. The issue arose again during the fall of 1916, a time of very stormy strikes in Petrograd factories and those of many other cities. The WIC Central Worker Group wished the organized factory movement to align itself with the left wing of the Duma (the Trudovik and SD factions). At a citywide meeting, the SRs and Bolsheviks opposed this idea, declaring that "it was time for revolutionary action not resolutions." Police reports from November 1916 noted the large number of factory collectives of all kinds taking shape, the frequency of their meetings, and the radical nature of their intentions and resolutions.

The interparty group at Arsenal adopted a radical stance as well. Voronkov specified that the SR cells were guided in this and other matters by "general party directives" and by "specific instructions" from district party groups "that began to have a more organized form.” For 9 January 1917, the Arsenal factory committee succeeded in bringing out the entire plant, which enhanced the prestige of Arsenal as a fully organized revolutionary plant with an effective factory committee. In advance of the 14 February State Duma opening, the district SR organization suddenly informed the Arsenal SRs that the scheduled demonstration "was postponed" (left socialists rejected the WIC worker group's plan for workers to go to the Duma).

Police reports about 14 February show that some eighty-nine thousand workers at 58 large defense-oriented plants struck. Attempts on the part of leaders to collect crowds largely failed, as most strikers simply went home. Workers at three sites carried banners with the slogans "Down with the war! Down with the traitorous government! [and] Long live the Second Russian Revolution!” When students attempted to join the marchers the police dispersed the columns. Police reports and other data from the fourteenth portray SR, Bolshevik, and Mezhraionka activists on the Nevskii, organizing and attempting to magnify the strikes and demonstrations. The moderate socialists had such high anticipations that they set up a command post at a downtown office in order to transmit by phone minute-by-minute accounts of the situation in the streets to Kerensky at the Duma. The prospects for an uprising had sufficiently alarmed the authorities that by mid-month they called in supplementary Cossack forces and worked out a plan of deployment. ${ }^{39}$

The memoirs of Voronkov and other workers amply recount the growth and activism of factory-level party and interparty groups during the last six months of the old regime. A multiparty group at the Diuflon plant discussed current events and agreed on "joint activities in the struggle." The SR Milchik, an Erikson worker, 
recalled that "it became obvious to everyone that the moment for some kind of action had arrived." Party activists, whose "influence grew by the hour," encouraged workers to take a stand. It was not so much a question of real organizations, "rather Bolsheviks, SRs and Mensheviks had their groups at each factory, with varying degrees of influence, who maintained connections with one another other at the factories. Most demonstrations were worked out at the factories among the groups." He remembered "numerous gatherings, meetings, clubs and leaflets. Everyone was interested in politics, such as the latest speeches of the leftist deputies in the Duma. Factory discipline slipped." 40

Voronkov supplemented Milchik's recollections by specifying the formation of district organizations for the SRs and other parties of the Vyborg District. At the Narva District's huge Putilov plant, recalled Kapytianov, five circles of various affiliations took shape and, during the course of 1916, expanded from three hundred to over two thousand members. By February numerous meetings at Putilov and other plants openly discussed the war, governmental inadequacies, and other critical problems. Endless strikes and demonstrations proffered, according to Kapytianov, radical slogans such as "Down with the tsarist regime!" ${ }^{11}$ Numerous archival memoirs of workers in the capital's industrial giants detail the stormy labor movement during the months and weeks before the February Revolution. They describe the laborers' growing hostility toward the government and the war and the increased tempo of circle and party work. Of special interest is the revolutionizing of the relatively conservative Arsenal workforce. In view of this evidence, who can possibly aver a lack of socialist awareness or incessant socialist-worker interaction?

\section{International Women's Day: What the Records Say}

Central to the questions at hand are the 23 February (International Women's Day) strikes and demonstrations that eventually culminated in the overthrow of the tsarist regime. In the past, I have suggested that leftist socialists (primarily SRs, Mezhraiontsy, and Menshevik-Internationalists) encouraged strikes and demonstrations for the twenty-third in the hopes that it (or any other occasion) would serve as the “beginning." Iurenev (Mezhraionka), Ermanskii (Left Menshevik), Markov and Voronkov (SRs), Kaiurov (Bolshevik), and others provide testimony about the prolonged, feverish preparations of individual party groups and the joint socialist bureau. Only the Bolshevik leadership, largely unheeded by its rank and file, urged restraint in the belief that the following spring would be more propitious for revolutionary outbursts. Bolshevik leaders had exhibited a similar restraint during November 
1916. Bolshevik hesitancy notwithstanding, most socialists had come to feel that, in light of extraordinary societal tensions, any event might spark a revolutionary conflagration. Even the cautious Bolsheviks issued an early February proclamation that stated, "Let each day in the history of the workers' movement become a call to demonstrate. [Let] the trial of the workers' [Duma] deputies, the Lena massacre, the first of May, the July shootings, the October days, January 9, and the like serve as a summons to mass action." ${ }^{42}$ By early 1917 the Russian public and especially workers could only construe such language as a call for an uprising.

Pertinent archives reveal little new about the background to the International Women's Day demonstrations, the first day of the revolution. The police noted the daily strikes and unrest immediately prior to 23 February, including several textile factories, the Obukhov plant, and Putilov, where the 21-22 February disturbances led to a lockout. At the same time, the police conducted relentless roundups of known socialists and issued arrest warrants for, among others, the SRs Anasovskii and Ostapenko, WIC workers' group activists at the Prorokhov plant; most Menshevik WIC leaders were already sitting in Petrograd jail cells. Longley's seemingly reasonable suggestion that the Putilov strikes and lockout of 21-22 February demarcated the actual beginning of the revolution overlooks the significance of two factors. ${ }^{43}$ On the twenty-third the strike wave spread to numerous plants, drastically expanding the number of strikers, and only on that day did demonstrations reach the Nevskii to occupy central space both symbolically and geographically. Also on the twentythird the police arrested a worker demonstrator with copies of a Mezhraionka leaflet calling for International Women's Day strikes, indicating the likely role of revolutionary agitation. ${ }^{44}$

Some anomalies arise in available police records about the weeks and days prior to 23 February. Daily agents' commentaries about incessant strikes, especially in textile plants and finally at Obukhov and Putilov, eschew mention of politics or of socialist leadership or even involvement. Yet, as noted, other police reports chronicle round after round of simultaneous repressions against the socialists and anarchists motivated by their actual and potential involvement in unrest. As of January-February 1917, revolutionaries, their activities, and their arrests on the one hand, and factory workers and their strikes on the other, hardly existed on two separate planes, in splendid isolation from one another, although this latter evaluative twist would fit some theories of the revolutionary movement. After all, if by early 1917 the socialists acted separately from the mass movement, how did this suddenly come about and why did the government bother with them at all? To the contrary, massive evidence, including the summary reports from the police and minister of the interior reports already quoted, asserts extensive socialist involvement in the mass movement and, 
furthermore, establishes the existence of a web of inter-locking links among the various party organizations at city, district, and factory level and between them and the workers' and students' movements in all their aspects. By February 1917 no isolation existed within the Petrograd socialist, radical intelligentsia, worker, student, and (perhaps) soldier milieus. Inspection of all available sources, in place of cursory, piecemeal perusal and selection, establishes this vital insight into the dynamics of the February Revolution.

Voronkov's recollections, although unusually reticent about 23 February, are suggestive. At its last session before the twenty-third, the Arsenal's factory committee discussed the bread crisis and reached the conclusion that since "we are better supplied than others, bread won't suffice [as a reason to strike]. But we will prepare.” As members of the Vyborg Consumer Cooperative, an organization largely administered by Left SRs and Menshevik Internationalists, Arsenal workers had good supplies, which explains the factory committee's doubts about bread as a strike motivation for the plant's workforce. Regardless, initiatives had come down from party organizations to use the bread crisis to promote demonstrations, prompting the discussion in the first place. The asseveration "we will prepare" suggests that, despite the inadequacy of the bread issue for their plant, Arsenal leaders resolved nonetheless to aim for demonstrations on 23 February. The recollections of Markov, also an SR at Arsenal, confirmed widespread discussion at this time of the upcoming demonstrations for the women's holiday. Voronkov's next comments were about 23 February itself: “The call came at 2 p.M. [to] stop work. We all came out. We met on the street to organize the group. I made a speech to explain what should happen. We went to the Nevskii [Prospect]." Gavrilov, a Bolshevik at Rozenkrants, recalled how "a meeting of women workers took place to discuss International Women's Day, as a result of which the stormy meeting pronounced the strike."45 Years earlier socialists had introduced and propagandized International Women's Day and, in 1917, specifically promoted it, a matter of vast symbolic and practical significance.

All this fits the hypothesis that various parties had selected International Women's Day as the next opportunity to initiate an antitsarist uprising (long experience taught the socialists that they could not simply decree revolution). Other evidence supports this idea as well. Ermanskii wrote that "by 23 February ... a [special] issue of Trud [the Petrograd cooperative newspaper] had been widely distributed. On the day itself, the [Left Menshevik] Initiative Group and other party organizations also distributed illegal proclamations throughout the factories." Ermanskii then stated his belief that the "militant slogans" employed in these publications played a distinct role in transforming the strikes into an uprising. Iurenev recalled that already in late 1916 the Mezhraionka began to prepare for 23 February. He pointed out that the 
intersocialist group argued about what slogans to use and therefore decided to allow the parties to issue proclamations separately. Even low-level Bolshevik groups joined in the preparations. ${ }^{46}$ Although only the text of the Mezhraionka 23 February proclamation has surfaced, Ermanskii and Iurenev implied that others came out or at least were planned.

The 23 February strikes and demonstrations - hardly the "hunger riots" referred to in some studies - did not appear out of nowhere, although war weariness and fear of hunger doubtlessly spurred on many women and other workers. Voronkov recollected the "call" to come out on strike, but failed to specify from whence it came. In other instances, he noted that district party organizations issued summonses to strike and instructions about tactics and slogans. His reticence about the call to the strikes that initiated the February Revolution may simply reflect the period (the 1920s) when he recorded his memoirs. Regardless, he indicated how the "bread issue" served as a conscious mode of promoting strikes and demonstrations. We should listen closely to Voronkov's voice as he next describes how on the street outside the plant he "explain[ed] what should happen. We went to the Nevskii." On 23 February, Voronkov explained "what should happen" not as a rank-and-file worker but as a WIC worker group member, SR activist, leader of the underground movement at Arsenal, and future famed leader of the factory committee movement. He was a person deeply enmeshed in the chain of command of his district and city party organization, as well as of the general Petrograd socialist movement. Three summary points require reiteration. International Women's Day was a socialist holiday solely promoted in the past and in this instance by revolutionary groups. These same groups had settled on the bread issue as a lever to launch worker protest. Mass strikes, demonstrations, protests, and other actions, their recent past failure to work the desired result aside, had the intention of revolution.

\section{The Revolutionary Days: The Published Record}

The events of the tumultuous days of 23-27 February are roughly as follows. The all-socialist coordinating group that had already met prior to 14 February and 23 February now met on the evenings of 23, 24, and 26 February in order to forge agreements about how to proceed. Because right and left socialists had some disagreements in approach, a left socialist group also arose, consisting of SRs, Mezhraiontsy, Menshevik Internationalists, and Bolsheviks, the last of whom participated least actively. On 23 and 24 February, the leftists wished to push forward to revolutionary goals, whereas the rightists were much more cautious about a movement they did not feel they entirely controlled. Meanwhile in the factories, interparty committees, 
unburdened by such conflicts, met together and encouraged and led the strikes in the streets. Sickness fund offices usually served as factory meeting places.

District SR, Bolshevik, Mezhraionka, and Menshevik Internationalist groups also held meetings aimed at intervening in the movement. Evidence of the transmission of slogans and plans from the left socialist or all-socialist coordinating groups down to district organizations is incomplete but suggestive. One example concerns a 26 February joint meeting of Vasil'e-0strov Bolsheviks and Mezhraiontsy, which passed resolutions modeled on those approved by the left socialists the previous evening. In addition, packets of leaflets To the Soldiers issued by the SR-Mezhraionka bloc were handed over for distribution in the streets. ${ }^{47}$ Published police reports and several Soviet historians have noted the role of workers' cooperatives as meeting places for district-level interparty groups, which made decisions about future activities and transmitted them to factory-level organizations.

When it became obvious by the twenty-fifth that the unusually vigorous demonstrations had taken on a distinctly revolutionary cast, the right socialists decided to come out strongly for their continuation and transformation into revolution. They even leapfrogged the leftists by first issuing the call for workers to elect delegates to the soviet. They hoped to exert control over the movement, which otherwise would have further developed under left socialist guidance. Meanwhile, the SRs and the Mezhraiontsy urged caution about the election of soviets, which, until the soldiers came over, could not be protected. Simultaneously, the left socialists launched a campaign to agitate the armed forces. The police reported that the SRs were calling for the "unification of the soldiers with the people.” The Mezhraionka, often acting in tandem with the SRs, displayed the greatest activism in publishing propaganda during this period. Acting alone or in a bloc with the SRs, they issued a series of proclamations (on 23, 24, and 26 February) to the workers and soldiers urging continuation of the strikes and demonstrations, the overthrow of the existing government, and the formation of a "Provisional Revolutionary Government." Members of all the parties agitated verbally in the streets, factories, and schools, marched at the head of demonstrations, and addressed crowds gathered at squares in the city center. Additionally, the Mezhraionka leaflet on the twenty-fourth suggested to workers that they persuade soldiers to join the movement, and the two SR-Mezhraionka leaflets of the twenty-sixth contained special appeals to soldiers. ${ }^{48}$ With the achievement of full worker participation by 25 February, those in uniform had become the key issue.

The general strikes of 25 and 26 February brought city services and work to a standstill in the capital. Several workers' districts passed into the hands of the rebels. At this point, the regime ordered military units to fire on demonstrations, 
which transpired on the twenty-sixth. Several units balked, whereas others shot, causing significant casualties. That evening, units of the Pavlovskii Guards Regiment that had fired on demonstrators mutinied but were brought under control by other units, who arrested a number of rebellious soldiers. News of these events sped throughout the city. Early the next morning, the entire downtown Petrograd barracks complex near the Tauride Palace, home of the State Duma, rebelled and joined the revolution. Workers and soldiers attacked and opened up various jails, subverted other garrisons, attacked police stations, and appeared in huge numbers at the Tauride Palace. Revolution had occurred. By evening, the fledgling Petrograd Soviet gathered at the Tauride Palace.

Surprisingly, the neatness of this chain of events has never struck scholars, captives of the "anonymous, spontaneous" theories. The former Right Menshevik Iordanskii raised this very question in Molodaia Gvardiia in its issue for the revolution's tenth anniversary. Events on 26-27 February, he claimed, "did not happen chaotically. ... There was a plan and an organization." We will return later to Iordanskii's ideas, without necessarily fully subscribing to them. They serve here to intimate that the February Revolution was not self-evidently spontaneous.

\section{The Revolutionary Days: What the Archives Say}

For narrative clarity, the following survey of new evidence about the tsarist regime's last days is interspersed with some published data. This evidence hones our awareness of joint socialist involvement in every step of the revolutionizing situation.

One summary police report about 23 February noted the active strikes in the Vyborg District in protest of bread shortages. Striking workers "called out" other plants and by 1 P.M. had managed to cross the Neva onto the Nevskii Prospect. When dispersed at one place, they gathered at another, blocking city transportation. Marchers carried banners, sang revolutionary songs, and shouted "Give us bread!” Only by 7 P.M. were order and traffic restored. Rumors spread that the next day cabdrivers intended to carry only strike leaders. That evening, Voronkov attended a citywide WIC worker group meeting, where the Mensheviks argued for support of the Duma, whereas the SRs and Bolsheviks urged "political demonstrations." One speaker wanted workers to "meet at the factories the next morning to go to the Nevskii," an idea Vyborg workers backed enthusiastically. Markov and Voronkov recalled that by evening all Vyborg District party organizations summoned their members for special meetings. ${ }^{49}$ The parties, directly implicated in the day's outbreak of strikes and demonstrations, responded instantaneously to signs of workers' resolve, rather 
than remaining passive as commonly thought.

Police reports from the twenty-fourth ominously counted the striking factories (131 with 158,583 workers). Workers came to work, voted to strike, and then either went home or, as activists requested, into the streets to demonstrate. An outside agitator told the Aivaz strikers to demand the government's overthrow, an action, he said, supported by white-collar, railroad, city-transport, and postal-telegraph workers. When Arsenal workers struck at 10 A.M., some of the elders tried to block the way. Voronkov impatiently overrode their objections: "This is not a struggle for bread! It is a struggle against the autocratic political regime. We cannot stand aside. After me!" The workers shouted "Hurrah" and filed out into the streets to "take out" other plants and march on the Nevskii. Milchik (an SR from the Erikson plant) recalled that workers who had weapons carried them, while others put large bolts and other objects into their pockets. On the Nevskii, one group of 300 workers listened as an orator "called for the government's overthrow" and summoned them to a meeting at the Kazan Cathedral at noon the next day. As the day progressed, strikers aggressively "brought out" non-striking factories. An arrested woman, Raskina, shouted to the police, "You'll soon be hanging by your heads!" During one clash, Voronkov was dealt a painful blow by a Cossack whip. Many students joined the demonstrations. The police characterized the day's events as "very alarming."

Police reports from 25 February registered demonstrators' new militant tone. Crowds openly ridiculed police officers and severely beat one sergeant. When the Bolshevik Burtsev saw Voronkov that morning at the Arsenal, he had "tears in his eyes," thinking the Cossack's blow fatal. Just as the factory strike leaders agreed to continue the demonstrations, the Moskovskii Regiment arrived to break up the meeting. Arsenal workers hurried off to join others headed for the city's center. Demonstrations, numbering in one case 6,000 and in another 17,000 persons, carried numerous red flags and sang revolutionary songs. Huge crowds with banners at Znamenskii Square and at the Kazan Cathedral listened to orators. One police report warned that "military units failed to act." Another claimed that soldiers deployed to reinforce the heavily outnumbered police "are not expressing sympathy for the crowds but don't act to control the streets and in some cases have been seen having conversations with demonstrators, who give them apples and cigarettes.” The First Don Cossack Regiment also failed to take action. Only the Finland Guards Regiment showed motivation. Milchik recalled that by the twenty-fifth some Volynskii Regiment soldiers had already joined the crowds in Vyborg. ${ }^{51}$ The police lost control, as city services ground to a halt. Among the 200,000 strikers, many still called for "bread," whereas most used political slogans. Students at a large university meeting voted to strike in solidarity. 
During the day the Anchar Bolshevik worker Aleksandrov and other workers from his plant and the nearby Putilov marched on the Nevskii. Upon returning home by foot (transport had halted), they met the SR E. E. Flekkel, head of the Peterhof workers' evening school, where all party members met. She gave them passes to the evening city duma session where Kerensky and Skobelev were scheduled to appear. They trudged wearily back to the city's center. At the meeting, Kerensky, Skobelev, cooperative leader I. Vol'skii, and several factory workers spoke in highly radical tones. Meanwhile, speakers at an earlier WIC workers' group meeting had urged the election of delegates to the workers' soviet, even specifying Monday morning, 27 February, for the factory elections. ${ }^{52}$ These two widely attended sessions took several vital decisions about prolonging the strikes, aiming at revolution, and electing soviet delegates. The socialist leaders thus crucially touched base with their constituencies. A provocateur reported that on the same evening of 25 February sailors of the Second Baltic Fleet Marines (Petrograd) conspired to mutiny at 6 A.M., 27 February, seize arms, arrest officers, and take "further action." 53 These decisions of the WIC workers' group and the Second Marines-imply the rise of a plan or, at the very least, a general orientation to commence actual revolutionary steps two days later.

Sunday, 26 February, witnessed vast strikes and demonstrations. Rumor claimed that police captain Krylov was killed by Cossacks in revenge for the police's wounding of a Cossack officer. At Znamenskii Square a soldier and a junior officer addressed the large crowds. According to students who recognized him, Kerensky dramatically rode up on horseback to the Znamenskii, where he "spoke powerfully" in favor of elections to the soviet of workers' deputies and urged the workers to organize, arm themselves, and march to the detention center to free those held there. (By the twenty-fifth, the right socialists had commenced calling for soviets. The government's recent arrests of right socialist activists accounts for the idea of opening the gates of the detention center.) Among those arrested at the demonstrations on the twenty-sixth were the SRs P. Kraskovskii and A. Pukhov. One report noted that the fourth company of the Pavlovskii Regiment had fired on the crowds. At the Cathedral of Christ the Savior other Pavlovskii soldiers taunted the police by calling them "pharaohs" (opprobrious eponym for police headgear) and fired volleys at them. These soldiers returned to their barracks and mutinied, after which they were subdued and disarmed by soldiers from the nearby Preobrazhenskii Guards Regiment. ${ }^{54}$

Much now hinged on worker' responses to the shootings and what soldiers would do the next day. On the twenty-sixth, the SR-Mezhraionka alliance issued two sets of leaflets, one to workers and the other to soldiers, that urged continuation of the demonstrations, overthrow of the government, and adherence of soldiers to 
the revolutionary cause. Eyewitnesses reported how workers and socialist activists, including the Left Menshevik Kapelinskii, the Mezhraionets Iurenev and the Left SR Aleksandrovich, harangued soldiers in the streets. Direct socialist agitation of soldiers that had begun on the twenty-fourth intensified by the twenty-sixth.

During the evening of 26 February, the all-socialist group held its last meeting of the tsarist era, with Kerensky, Shliapnikov, Aleksandrovich, Iurenev, and a stellar group of the capital's left and right socialist leaders in attendance. The next day they would become the executive committee of the soviet. Iurenev and others recall the meeting as "stormy." Indeed on some matters left and right socialists worked at cross purposes the next day. However, Iurenev and the other leftist memoirists such as Sukhanov and Ermanskii do not reveal what the argument was about. Right socialists such as Kerensky and Zenzinov create the impression that the leftists, failing to realize the imminence of revolution, urged caution. Kerensky claimed that he suggested the necessity of preparing for "decisive events" within the next day or so, whereas Iurenev objected that the soldiers and workers were going separate ways, and the parties, instead of "living in a daydream," should engage in long-term propaganda for a better day. The authorities knew in advance of this meeting and had laid plans (perhaps deflected by the Pavlovskii Regiment's uprising) to arrest the participants, who, in the words of one police report, were planning "to use the current disorders for revolutionary goals and assert control of them." 55

If the leftists gave their moderate colleagues the impression that they had no hopes of revolution on the twenty-sixth, then they were not being entirely forthcoming. Aleksandrovich and Iurenev had just spent the day on the streets speaking to the soldiers, among whom all observers noted growing disaffection. Although at least one unit had fired on workers, others refused and, furthermore, the Pavlovskii soldiers had rebelled, news of which had traveled like lightning around the city. In other words, they had no reason to posit the soldiers' growing conservatism. A surer measure of Aleksandrovich's and Iurenev's outlook is the leaflet they composed after leaving the joint socialist meeting and had printed for distribution the next morning: "We Bolsheviks, Menshevik SDs, and SRs summon the proletariat of Petersburg and all Russia to organization and feverish mobilization of our forces. Comrades! In the factories organize illegal strike committees. Link one district to another. Organize collections for the illegal press and for arms. Prepare yourselves, comrades. The hour of decisive struggle is nearing!” The authors also praised the Cossacks for attacking the police and the Pavlovskii soldiers for rebelling. ${ }^{56}$

This does not suggest blindness to the imminence of revolution. More likely, the left socialists, wary of right socialist attempts to assume control of the mass movement, wished to dampen the latter's enthusiasm. For weeks right and left had 
maneuvered for control of the movement that everyone had long since recognized as revolutionary. On 14 February, the left socialists had prevailed, when workers had struck without going to the Duma. Now, although left socialists were more directly implicated in the grandiose strikes and demonstrations, the right socialists seized the initiative by joining in the call for the regime's overthrow with the addition of the summons to elect the soviet. The left feared summoning the soviet prematurely, that is, until the soldiers came over. Judging from what happened the next day and from all too laconic participants' reports, at the joint socialist meeting on the evening of the twenty-sixth the right socialists, with Kerensky as their point man, proposed summoning the soviet the next day at the Tauride, to which the leftists objected. They were not against a soviet but did not want the moderates to summon it or for it to gather too early. Thus the leftists played down the mass movement to the right wing and then went out into the streets to encourage it in every way. ${ }^{57}$ An alternative interpretation would be that the left socialists, perhaps exhausted after a long day in the streets and discouraged by the day's shootings, found out about the revolt of the Pavlovskii Regiment after the socialist meeting and only then decided to pursue the matter by means of the quoted leaflet. Still, this leaflet precisely fits and expands the arguments of the entire series of SR-Mezhraionka leaflets issued between 23 and 27 February. Examined in toto, they reveal acute left socialist consciousness of the revolution's daily progress and steady, purposeful urging foward of workers and soldiers. ${ }^{58}$

Two provocateurs' reports of 25 and 26 February also command attention. On the twenty-fifth the SR "Kochegar" (identity unknown) reported that units sent to quell disorders were fraternizing with, protecting and, in some cases, even encouraging the demonstrators. "If this is allowed to continue," he warned, "and if control [of the units] passes to the leaders of the revolutionary underground, then disturbances will assume the widest character." Kochegar also said, "it is now possible to detect the leading center that issues directives; the leading central organ is nonparty [i.e., multiparty].” The very next day, the Bolshevik Shurkanov ("Limonin”) picked up just where Kochegar had left off. He precisely delineated how factory activists had promoted the movement and asserted control of it; how revolutionary circles had promoted slogans against the war and for the government's overthrow; and how by this time the "government was perceived as powerless," as a result of which, he predicted, "the movement ... would proceed to a final victory in overthrowing the government." Shurkanov also specified the next day, 27 February, as the day the soldiers would mutiny and the soviet would form. This marked the third forecast of the twenty-seventh as the day of crucial action. ${ }^{59}$

Before proceeding to the fateful day of 27 February, we should note that the 
evidence presented so far contradicts the view that dilatory socialist leaders and organizations responded to spontaneous hunger strikes only on the third day of their duration. True, on the twenty-fifth the right socialists, after initially urging restraint, finally relifted the revolutionary cudgel. Yet, prior to the twenty-third, on the twenty-third itself, and on every succeeding day, leftist socialists had instigated strikes, demonstrations, and all other possible antigovernment actions. Police records, witnesses, and memoirists specify that on 23 and 24 February revolutionary activists in the plants called for strikes and literally led the columns of demonstrators on the Nevskii, while beginning on the twenty-fourth socialist activists worked the crowds in the streets and targeted soldiers with verbal and written agitation of indelibly revolutionary content. Party and joint party meetings gathered each evening. Socialist parties and blocs issued leaflets with slogans calling for the regime's immediate overthrow. These leaflets, by the way, constitute a veritable road map of socialist attitudes and actions prior to and during the entire February crisis. Well before 23 February the socialists decided to utilize the hunger issue to promote antitsarist feeling. Already on the twenty-third the original bread slogans were partially supplemented and then, by the twenty-fourth and especially the twenty-fifth, mostly supplanted by overtly political ones, such as "Down with the autocracy!" From the outset, socialist activists with revolutionary slogans and therefore, it follows, revolutionary intentions, helped spur, and then injected themselves directly into, the movement. However we ultimately characterize the exact degree of socialist agency, the onset and unfolding of the revolution was not as spontaneous as we have thought. This is the case because the constituent elements of the spontaneity theory do not hold water.

Early on the twenty-seventh, before they had complete news about the uprising of the nearby guards regiments, the right socialist leaders Kerensky and Chkheidze and other deputies of the prorogued Duma gathered at the Tauride. For the last time, Kerensky and Chkheidze urged the feckless Duma members to take action in the Duma's name. ${ }^{60}$ This tactic having again failed, the moderate socialist Duma deputies, augmented by Right Mensheviks and SRs just liberated by workers and soldiers from the detention center and jails, proclaimed themselves the Provisional Executive Committee (of the as yet nonexistent Petrograd Soviet). Kerensky arranged their headquarters in the Trudovik faction's office. There they wrote, sent to the Duma's presses for printing, and directed out into the city a proclamation in the name of the Provisional Executive Committee that called for workers to elect soviet deputies and send them to the Tauride. They also dispatched delegates to nearby units and even telephoned sympathetic officer acquaintances with the admonition to report to the Duma. 
Meanwhile, the left socialists, who focused their activities in the streets and factories, issued a string of leaflets to workers and soldiers, early in the day urging continuation of revolutionary actions and later on calling for formation of a provisional revolutionary government and elections to soviets. The Bolshevik I. Gavrilov, a Rozenkrants worker, claimed that his party sent down directives to demonstrators "not to go in groups, arm themselves and build barricades," which, if correct, suggests that even on the twenty-seventh the Bolsheviks irrelevently visualized a 1905 type uprising. Finally, to counter the right socialist summons to the Tauride Palace, the left socialists urged delegates to come to the Finland Station as the center, in the words of one of their leaflets, of the "new revolutionary government based directly upon the revolutionary workers and soldiers." Huge crowds of workers and soldiers converged upon the Finland Station. One woman worker, just freed from the city jail, went to the station where she and others waited deep into the night. At 10 P.M. a large group of Arsenal workers arrived, shouting to the soldiers, "Brothers! We are with you." ${ }^{61}$ Regardless, the Finland Station was not destined to be the locale of the Petrograd Soviet.

The superior location of the Tauride Palace, at the city's center and quite near the huge barracks complex of the guards regiments, whose mutiny toppled the old regime, ensured that it would be the locus of the revolution, rather than a railway station in a shabby workers' district across the Neva. The Tauride and its environs already had a governmental cachet, in addition to which the right socialists had stolen the march on the leftists by agitating earlier and more methodically, first for the election of soviet delegates and then for sending them to the Tauride Palace. By evening, as thousands idled at the Finland Station, the left socialist leaders finally reluctantly trudged to the Tauride to join their right socialist counterparts for the inaugural sessions of the Provisional Executive Committee and of the Petrograd Soviet. Thus the revolution would be less radical than the leftists had hoped. Regardless, direct conscious socialist involvement characterized everything that transpired during the days of 23-27 February.

\section{The Mystery of the Soldiers' Revolt}

Still, further questions arise, especially about the soldiers' uprising. Historical accounts oddly denude the soldiers' uprising of political content, with the exception, of course, of numerous Soviet-era histories that simply assert Bolshevik leadership. Leaving aside those claims (elections to the soldiers' soviet and unit committees a day or so later disclosed the stark limits of Bolshevik influence in the capital's units), one can draw attention to two Soviet studies that note the activities of various 
socialist groups and especially the SRs in the mutinous regiments. Leiberov describes the role in the garrison uprising of a "group of officers, noncommissioned officers, and soldiers, [associated] with the SR party." He also asserts that soldiers of the Volynskii, Litovskii, and Preobrazhenskii regiments and the sixth Sapper Battalion were under SR and to a lesser extent Bolshevik and Menshevik influence. Shatsillo evaluates the matter similarly, noting the "significant influence among the soldier masses [of various parties] and especially of the SR." No one has noted the passage in Sukhanov's memoirs, in which he asserts, without further detail, that "one thing is certain: there were great numbers of politically conscious and party elements in all the units of the Petersburg garrison ... [who] not only were capable of taking up the movement, becoming its center and lending it the inspiration of some political generalization, but their doing so was inevitable" (recall the SR police spy Kochegar's comments noted above). In this connection, at the 28 February session of the Petrograd Soviet the Left Menshevik-Mezhraionets I. Kroshinskii drew attention to the role of "propagandists ... in the collapse of the army." Other than data about Bolshevik-SR agitation of the Vyborg District 181th Regiment and Mezhraionka influence in the suburban 172nd, no details have emerged. ${ }^{62}$

A series of pamphlets written by I. Lukash about several of the guards regiments during the February days and a memoir by the famous T. Kirpichnikov who led his regiment in the uprising, each published during 1917, as well as several later accounts, all scrupulously omit any mention of political themes, parties, or anything that would shed any light on this matter. This or that event occurred, the soldiers suddenly rose against their officers, and mutiny resulted. ${ }^{63}$ The uprising, one would think, took place in a complete vacuum.

Several other sources provide clues to a more probable alternative. The reader may recall that members of the Second Marines, a unit stationed in the city, decided on 25 February to mutiny on the morning of 27 February. Two sources confirm that the marines had already rebelled when the other guards regiments mutinied early on the twenty-seventh. Of three identifiable persons who led the Second Marines in various activities on 27 and 28 February, two were SRs. ${ }^{64}$ That a provocateur recounted discussions at a deeply conspiratorial meeting in this unit a few hours afterward strongly suggests socialist involvement. Provocateurs were by nature members of parties and only as a party member would a spy, whose report revealed that he was not even a member of the unit, have been able to attend the meeting or otherwise ascertain what happened there. In a similar vein, a memoirist, whose unit had just undertaken to guard the Peter-Paul Fortress, recalled that on 26 February a soldier, also later revealed as a provocateur, gave a speech urging "help for the workers" that "greatly influenced" the unit in its later actions. ${ }^{65}$ By a strange twist, these laconic 
reports about provocateurs outline underground party activists' roles.

A more substantial account is that of F. Sorokin, whose Marine Guards unit was reassigned from the front to Tsarskoe Selo on 15 February, just in time for the revolutionary turmoil. Sorokin recalled that his company was the unit's "political center," where all the "activists" gathered. They maintained contact with like-minded individuals in other companies by meeting at the lazaret (clinic). Sorokin wrote that upon the unit's arrival he attempted to contact revolutionary organizations in Petrograd and, with great difficulty, reached a certain "Kolia” from the Franko-Russkii plant. Kolia came every day to bring news and newspapers but, claimed Sorokin, was not a member of a revolutionary party. When unrest began in the nearby capital, members of the unit fretted that they would be used to attack the crowds. On the twenty-sixth Kolia arrived late with the news that Izmailovskii and Pavlovskii units had fired on the crowds and that some factory committees had already elected delegates to send to the Tauride Palace. "Thus a revolutionary kernel had formed. We were in ecstasy," recalled Sorokin. Early on the morning of the twenty-seventh, Kolia came again, saying that "he had to find out about the mood in the battalion." He then spoke about meetings that would take place that day in the factories to elect deputies and said that "he would tell the socialist delegates at the State Duma about the mood of the sailors and their decision not to submit to orders." The next day he arrived with news of the successful revolution. Many Tsarskoe Selo units began their procession to Petrograd. ${ }^{6}$ Despite Sorokin's delicate demurral (because of the 1932 publication date of his memoir?), Kolia was likely a member of a party. After all, he hardly arrived on 27 February as a mere concerned citizen to find out the mood of the sailors and report it back to socialists at the Tauride Palace. Furthermore, he was not a Bolshevik, since had he been, a 1932 publication would hardly have foreborn to mention it. These memoirs adumbrate a broad phenomenon.

The related revolutionizing of units at Tsarskoe Selo and nearby Oranienbaum also bears on this matter. Forces in the area were heavily reinforced on or about the fifteenth of the month, in part to protect the tsar's family at Tsarskoe Selo and in part for potential use against the expected disorders in the capital. On the twentyseventh these units refused to obey orders, negating the authorities' intentions. Furthermore, on 28 February and 1 March, these same units descended on Petrograd en masse to join the revolution. This démarche buttressed the new government in hazardous circumstances. Memoirists and Soviet-era historians have discussed how these units passed over to the revolution, especially in light of their relative isolation from Petrograd's intensely propagandized atmosphere. As elsewhere, many socialist activists served in these units. Such individuals in Sorokin's newly arrived unit had established only limited contacts in the city, whereas those in units long in place 
would have had firmer ties.

Soviet-era historians Rozental' and Cherniaev agree that revolutionary circles played a role in these units' rather orderly mutinies, but, as Cherniaev demonstrates, no agreement prevails about where credit lies. One soldier-memoirist attributed leadership of the Oranienbaum mutiny to the Bolsheviks S. I. Petrikovskii and S. Morisov. Petrikovskii countered that the "former worker at the Trubochnyi plant, G. B. Strumillo [a Left SR] led . . . the group of soldiers who carried out the uprising." A third memoirist recalled it as an "almost completely spontaneous uprising of the soldier masses," and a fourth admitted that the "soldiers said that a certain officer led the movement, but I did not see this officer and still don't know if he existed or not." 67 In any case, the extraordinarily smooth "uprising" culminated in a march in ranks (as witnessed by Mstislavskii and others) to Petrograd. Revolutionaries were on the spot, and spontaneity of the soldier masses was hardly the only factor. This was the whole point of Sorokin's memoir, which, remarkably for its time of publication, made no case for the Bolsheviks.

\section{The February Revolution: Rehearing the Voices}

This leads us back to the place where we began. Were the February events spontaneous, the result of plans and leadership, or a combination? Furthermore, if plans and leadership played a role, from whom and under what conditions? The reader will doubtlessly recall the war of conflicting quotations of participants and eyewitnesses of the February events. The Bolshevik F. Raskol'nikov, at the time a Kronshtadt sailor, insisted that "it is incorrect to say that [the revolution] came unexpectedly." Even rank-and-file sailors, he asserted, let alone experienced revolutionaries, "felt the deep underground tremors." ${ }^{68} \mathrm{~V}$. Bazarov, an independent SD close to Sukhanov, Sokolov, and Gorky, seemed to take the opposite tack: "Thus appeared the spontaneous people's revolution of the waning February days.” But he then elaborated: "I say spontaneous because no one organization can claim for itself the honor of guiding the first days of the revolution." As far as he knew, "there were no revolutionary organizations at all, except for separate circles.” Although, continued Bazarov, "from the beginning of the year all the illegal organizations called for ... strikes and street demonstrations ... no one dreamed that three days of street demonstrations would be enough to bring the soldiers over to the side of the workers. When it happened, many were unclear about the political program of the soldiers." 69

Notice the seeming contradictions. As far as he knew "no revolutionary organizations" existed and yet "all the illegal organizations" called for the strikes and 
demonstrations. The claim that no organizations existed has to be seen in light of long-term internal socialist debates, in which moderate socialists essentially denied the underground organizations any real utility or status. For many moderate socialists like Bazarov, no "real" organizations existed, functioning "illegal organizations" notwithstanding (numerous anarchist, SR, Bolshevik, Mezhraionka, and Left Menshevik activists would have hotly disputed Bazarov's purely polemical dismissal, as should we). Bazarov's tying of spontaneity to the fact that "no one organization" could lay claim to leading the revolution's early phase is curiously worded. Indeed, no one organization could because the joint socialist group noted in many memoirs and called by Zenzinov the "headquarters" of the February Revolution had the honor. In fact, the left socialists, especially the Mezhraiontsy, the SRs, and the Left Mensheviks, were chiefly responsible since they campaigned most actively just before and after 23 February. Whether or not anyone "dreamed" that three days of demonstrations would bring over the soldiers is irrelevant. After all, why were socialists espousing street demonstrations and, from 24 February on, urging soldiers to join the workers in antitsarist activities? The only possible answer is, to cause the eventual effect, whether in one, three or ten days. The SRs had long argued and worked for precisely this turn of events, that is, worker demonstrations joined by rebellious soldiers to create revolution.

Episodes from Sukhanov's famous memoirs also bear directly on this question. Sukhanov first described, secondhand, the meetings of the joint socialist group on the evenings of 23 and 24 February. The right socialists, in consternation at worker militancy, urged that everyone "keep in step with the Duma," whereas "the Left . . . hailed the revolution with delight, and held that it was vital . . . to create fighting organizations of workers." Note that, if Sukhanov's account is accurate, already on 23 and 24 February the left socialists perceived the events as a "revolution." Then, at the 25 February WIC worker's group meeting, F. A. Cherevanin, usually a staunch defensist, suddenly outmaneuvered the left by first espousing elections to soviets. "Instructions for the elections," recalled Sukhanov, "were issued by this meeting. These instructions were instantly taken up by the party organizations and . . c carried out successfully in the factories." Sukhanov noted that on 25 February he interviewed Bolsheviks and SRs of Zimmerwaldist tendency and found them lacking "any strong, really authoritative centers." Somewhat contradictorily he then asserted that, of the socialist parties, "it was just the Zimmerwaldist centers that could principally influence the movement” and, he continued, they focused their attention "on immediate agitation based upon general slogans and the immediate furtherance of the movement." Sukhanov then insisted that he "know[s] that the political problem was never officially resolved or raised at the [joint socialist] meetings. They 
have great historical merit for having prepared the technique and organization of the revolutionary forces, nothing more.” A few pages later, Sukhanov stated that, as a person not formally a member of any party, he had not "the slightest influence on the controlling centers of the movement." At meetings, the left socialists, noted the author, manifested their "absorb[tion] . . . in serving the technical needs of the movement, forcing a decisive set-to with tsarism, and organizing propaganda and the illegal press." 70

Again, as with Bazarov, who was quite close personally to Sukhanov, we find the shifting and evidently contradictory language. There were no "strong authoritative centers" among the left socialists and yet precisely their organizations had the best chance to influence the movement. Note that, as regards the leftist groups, he reiterates variations of the phrase "centers of the revolution" or "controlling centers of the movement." Likewise, the left socialist organizations refused to confront the direct political questions but were "only" concerned with the "technique and organization" of the final confrontation with tsarism, including agitation and propaganda "based upon general slogans." If the final confrontation with tsarism based upon general slogans is not a political question, than what is? Additionally, the moderate socialist leaders gave the 25 February directive to elect the soviets, which individual party organizations, including even leftist ones, then picked up and helped carry out in the factories.

Socialists of the Sukhanov-Bazarov type used theory-loaded language with very precise meanings, requiring almost hermeneutical exegesis. From the text, it becomes clear that when Sukhanov claimed that the socialists were not considering the political questions, he meant that they were focusing on bringing about the revolution, whereas he wanted them to consider the form of government after the overthrow. He also wanted them to adhere to his concept of the revolution, that is, it should be exclusively political, in other words establish a purely bourgeois government, an idea many leftists already opposed.

None of this negates in any way the realities of Sukhanov's exposition. Socialist organizations existed and the leftists among them were especially influential. The left socialist group met repeatedly and laid down plans about further steps to overthrow the regime, and the moderates socialists gave instructions followed by all party activists to elect soviet delegates. To jump a day or so forward, when Sukhanov discussed Kerensky, Chkheidze, and the other labor leaders who met at the Tauride Palace on 27 February to form the "Provisional Executive Committee of the Soviet of Workers' Deputies," he noted that "it had only one assignment . . . to convoke the Petersburg Soviet of Workers' Deputies," a task "it performed splendidly." ${ }^{71}$ Keeping in mind that many factories had already elected deputies on 
the instructions of members of the joint socialist group and that those who gathered to proclaim themselves the Provisional Executive Committee were the same individuals from the aforementioned joint socialist group, one has an accurate picture, not consonant with "spontaneous anonymity."

I would like now to return to the remarks of Iordanskii published in Molodaia Gvardiia in 1927, especially as regards the soldiers' revolt that in essence transformed disorders into revolution. Iordanskii recalled meeting with Shurkanov (the provocateur whose secret report to the police has already received mention) around 20 February. Shurkanov told him that "the factories are boiling" and only the "experienced workers" were restraining the younger ones from outright rebellion. Iordanskii concluded, "All the experienced revolutionaries knew that a great event was approaching, but even on 26 February we didn't realize that it had begun.” (Of course, until the soldiers came over, no one could know.) On the morning of 27 February, serving women informed Iordanskii, who lived in a building just across from the huge barracks complex near the Tauride Palace, about the beginnings of the soldiers' uprising. Looking out the windows of his apartment, he could see soldiers milling near the gates in an unaccustomed fashion. Iordanskii phoned the Duma, from where the Right Menshevik M. Skobelev complained of the latest cowardice of the "Progressive Bloc." Archival reports indicate that Kerensky and Chkheidze had indeed attempted one last time to induce the Duma leaders to take action, an idea Miliukov once again stymied. Iordanskii repeated what the women had told him about the soldiers having headed for the Duma, to which Skobelev replied that another Duma session would take place at 11 A.M. to "discuss the events."

As a conscientious revolutionary, Iordanskii went out to advise the soldiers standing about in the streets. They confirmed that units had already gone to the Tauride Palace. Concerned about how the Duma would receive them, Iordanskii urged unity among the soldiers. The soldiers, members of the Probrazhenskii Guards, answered brusquely, "We have our people in other regiments as well." "You mean you have ties [with other units]?" queried Iordanskii, to which the soldiers said "Yes, without that we couldn't have carried this off. We've been meeting together.” Trying again to be helpful, Iordanskii suggested sending units to open the jails, to which the soldiers impatiently replied, "Yes, we know, they've already gone. We have to free the workers' deputies [presumably from the WIC workers' group].” The hapless socialist then suggested the arrest of members of the old regime. "Ministers?" they countered. "Ours are already taking care of that. They're bringing them all to the Duma." Iordanskii then understood, he claimed in his 1927 article, that "the uprising had its already established leadership" and his attempts to act as adviser were superfluous. 
Iordanskii later pondered the rapid progress of the soldiers' uprising. At 8 A.M. the Volynskii Guards mutinied; by eleven the jails were opened and the leaders from the WIC workers' group, who, he recalled, were not all that popular, were freed and making the rounds of factories to call for elections to the soviet. There was nothing chaotic about the way things transpired, claimed the author. Beginning with the failure of some units to fire on the crowds on the twenty-sixth, the events seemed to have had "planning, preparation, organization, and leadership." Iordanskii suggested the existence of a "hidden military organization" that had ties with "liberal generals" and the "antidynastic WIC" but entirely separate from the "historically revolutionary parties.”

Nonrevolutionary circles with ties to liberal generals may well have existed, but that they played the role Iordanskii ascribed to them stretches the bounds of probability. The revolt was profoundly antiofficer. Only officers of low rank and birth and connected with the historically revolutionary parties played any role or had any influence. Liberal antidynastic generals had no more to do with the soldiers' uprising than the antidynastic Progressists, who even on the twenty-seventh obdurately eschewed action, had to do with the proletarian uprising. Iordanskii perforce used Aesopian language. Writing in 1927 as a Communist, a fact he emphasized, he urged investigation of this matter. He implied that the soldiers' revolt was not Bolshevik in provenance, but he could hardly attribute it to other "historically revolutionary parties."

In considering this question we must recall several factors: evidence of special emphasis on the part of SRs to the propagandizing of soldiers; Sukhanov's chaste remarks (he deliberately forbore to say more because he was not an eyewitness) about the existence "in all the units" of revolutionary circles, who, in his view, would certainly have acted to give the movement definition and organization; Kochegar's comments about underground leaders with the potential to take over the movement in the military units; the assertions of established Soviet-era historians such as Shatsillo and Leiberov that many garrison units were under revolutionary and especially SR influence; and the subsequent election by these units of large numbers of socialists, especially SRs but also some Mensheviks and a few Bolsheviks, into their soldiers' committees and soviets. We must also take into account the above-mentioned tantalizing, albeit incomplete, bits and pieces of memoir evidence about soldiers and units, such as, for instance, the early mutiny of the Second Marines (which had identifiable SRs), and, above all, the verified existence of the SR Northern Military Organization with a branch in Petrograd. The putative role of an underground military organization, SR or otherwise, is as yet speculative, although I believe firm evidence of its existence will gradually emerge. The crisp progress of the soldiers' uprising and its 
almost seamless coordination with the workers' demonstrations suggest, as Iordanskii maintained, preparation and leadership..$^{73}$ One might recall the SR Northern Military Organization's leaflet quoted above: "organize. ... and wait for the call."

We have not read the memoirists fully or with close attention. Instead, we have elevated certain quotes, half out of context, to the level of profound historical truth, while failing to note rather considerable factual evidence susceptible to a very different interpretation.

\section{Rethinking the February Revolution as a Real Revolutionary Event}

Let us review several key points from this disquisition about the February Revolution. We will use a conjoined version of published and archival materials, the second of which refracts light through and expands upon the first to create something approximating the actual revolutionary event. Despite constant repression, by fall 1916 and winter 1917 revolutionary organizations had begun to grow and become active, from leadership levels all the way down to factories, academic institutions, and, evidently, military units. The leaders of the revolutionary parties began to coordinate their activities precisely because they considered the current crisis to be revolutionary in character. During February an all-socialist leadership group with origins in November 1916 joint meetings met regularly and continued to do so throughout the February days. Because of differences in outlook, the left socialists also maintained a separate informational group and the socialist Duma factions performed the same role for the moderates.

By late 1916, both sides of socialism had come out openly for revolution, with the rightists wishing to tie the revolution to the State Duma and the leftists opposed to this idea. All agreed, however, on the overall immediate goal of overthrowing tsarism. Internal documents of the parties and police reports about them show that they deliberately intended to use the economic crisis, especially the perceived bread crisis, for revolutionary goals. They encouraged demonstrations for bread and attempted to transform these into revolutionary uprisings. Evidence shows that by February workers, soldiers, revolutionary activists, figures in the Duma, and government officials were fully cognizant of the revolutionary nature of the situation. Any spark could suffice.

We should bear in mind the evidence about the Trudovik Duma group that by mid-February had abandoned parliamentary in favor of revolutionary activities. The latter included maintaining close contact with the underground SR movement so as to encourage and channel worker and soldier unrest toward revolution. This analysis 
can be expanded to the Social Democrats, with the partial exception of Bolshevik leaders. We should recall evidence about reviving circles and district organizations that passed down directives, which the factory level groups attempted to follow. We should hold in the forefront of our minds that the "bread question" had become a potent political issue that the radical parties consciously decided to use to promote strikes and demonstrations with revolutionary goals. Lest we forget, revolutionary goals meant the overthrow of the tsarist regime. By early 1917 bread or any other strikes were not depoliticized activities, as real events demonstrated with crystalline clarity.

With the approach of International Women's Day, the all-socialist group met but could not agree on slogans for the occasion. The left socialists, especially the SRs, Left Mensheviks and the Mezhraionka, along with low-level Bolshevik groups, spurred the demonstrations on 23 February, a socialist holiday. The right socialists, still smarting at the defeat of their plans as regards the opening of the State Duma on 14 February, were hesitant. The Bolshevik leadership held out for revolution during the spring, an approach spurned by the party's cadres. Because of the staunchness of the demonstrations on the twenty-third and unwonted Cossack reserve, socialists immediately intervened to prolong and deepen the disturbances, with the leftists, now including the Bolsheviks, displaying special energy. They issued leaflets, led factory strikes and demonstrations in the streets, held meetings at all levels, including of the joint socialist groups, and agreed on slogans to be used each day. By the twenty-fifth, the right socialists fully joined the movement as well and began to urge the election of soviets. On the evening of 26 February, the all-socialist group held its last prerevolutionary meeting, which was marred by left versus right socialist squabbling.

Regardless, on the twenty-seventh a group of right socialists, including Kerensky, Skobelev, Chkheidze, and several others from the cooperatives, joined by individuals freed from prison by soldiers and workers armed by soldiers, formed the Provisional Executive Committee of the Soviet and issued calls for factories and soldiers to send elected deputies to the Tauride. Meanwhile, every two hours or so during the turbulent day the left socialist leaders issued leaflets that both responded to the very latest happenings and urged the movement forward to full revolution. They attempted to have workers and soldiers send delegates to the Finland Station, out of the aegis of the Duma. Although huge crowds collected at the station, soviet delegates did not. The leftist leaders then made the hegira to the Tauride Palace to join the Provisional Executive Committee of the new Petrograd Soviet.

By evening the soviet executive committee exactly replicated the joint socialist group, previously an informational bureau for coordination of programs and 
activities, now a protogovernment. Before the twenty-third, the group made plans for International Women's Day and responded to the strength of the strikes. As of 25 February moderate group members issued the call to elect soviet delegates and on the twenty-seventh formed the executive committee and presided over the summoning of the soviet. On 25 and 26 February two separate sources mentioned the twenty-seventh as the day the soviet would be elected: speakers at the WIC workers' group meeting of the twenty-fifth and the police spy Shurkanov on the twenty-sixth. Relatedly, on the evening of 25 February members of the Second Marines plotted a mutiny on 27 February. Shurkanov also specified the twenty-seventh as the day the soldiers would mutiny. Taken together, these suggest a game plan as of the twentyfifth for decisive revolutionary action on 27 February. Regardless, socialist group members acted at each crucial juncture between 23 and 27 February.

Socialists had no specific plans in advance to launch revolutionary disturbances on 23 February and bring them to fruition on 27 February. What they did have, as overwhelming evidence indicates, was an orientation to promote strikes and demonstrations and, if they showed promise, to prolong them and push them toward revolution. Direct and organized socialist involvement and intervention occurred at every single stage. Our customary radical decoupling of the socialists from their popular constituencies is baseless. The tsarist regime certainly made no such mistake. Tsarist officials predicted a revolution with direct socialist involvement. Our propensity to ignore their opinions and pertinent evidence as well reflects our, rather than their, lack of perspicacity. They were correct: a revolution arguably similar to their expectations occurred. Iron-clad proof that revolutionized workers and soldiers always reponded directly to organizations such as the joint socialist bureau or a putative underground military group may never be available and is unnecessary. Historians do not operate in the realm of absolute proof, the scientific yearnings of past historiographers notwithstanding. To paraphrase Hegel, history paints its pictures in shades of grey. We need a new theory of the February Revolution that accounts for all available evidence to replace the old one that best accounts for several quotations. The total spontaneity theory now does greater violence to the historical record than this study's interpretation, which fits much evidence that many histories ignore and cannot reasonably account for. The February Revolution was not spontaneous, at least not in the absolute sense we usually employ.

Nor, for that matter, was it anonymous. We should recall that Kerensky and Chkheidze, as socialist deputies in the Duma, had achieved enormous fame, not only in the capital but throughout the empire and even at the fronts. Their speeches, and even those of Miliukov, were so antiwar and antiregime by late 1916 that the revolutionaries, including the SRs and Bolsheviks, reproduced and distributed them 
as proclamations. The personal files of Kerensky and Chkheidze in the archives contain thousands of letters from soldiers and workers written during the war. Both had direct ties with their respective SR and Menshevik organizations and with factory, cooperative, and other proletarian groups. ${ }^{74}$

The individuals chiefly responsible for the unfolding of the February Revolution were Kerensky, Chkheidze, Skobelev, Zenzinov, Rafes, Peshekhonov, Sokolov, Ermanskii, Shliapnikov, Iurenev, and Aleksandrovich. These individuals met repeatedly before and during the disturbances, some among them promoted the 23 February strikes, others called the Petrograd Soviet, and all formed the kernel of its Executive Committee, which became the real arbiter of Russia's fate. Neither individually nor collectively were they isolated from the mass movement in the districts, factories, and educational institutions, and, in all likelihood, military units.

Historians have paid insufficient attention to the multivoiced revolutionary movement of the months preceding the February Revolution. Moreover, in a bizarre maneuver, historiography has projected Bolshevik inaction of February 1917 onto the entire socialist movement. By early 1917, socialists and anarchists, their organizations and groups at all levels, their intentions, resolves, and actions, in a word, their agency, intermeshed with the motivations of millions of workers, peasants, soldiers, and intelligenty, their war weariness, fear of hunger, hardship of every kind, and sheer political frustration, that is, legitimately spontaneous elements. The final coalescing of agency and contingency fashioned a revolutionary weapon potent enough to uproot and topple the 300-year Romanov dynasty. Revolutions always have this character, whereas truly elemental events lead to chaos. Socialists could not decree a revolution, nor could spontaneous worker, soldier, and student disorders create one.

Analysis of linguistic usages about the February Revolution sharpens this insight. Contemporary observers utilized a language of spontaneity unhesitatingly combined with that of socialist involvement. One police report simultaneously worried about the "strivings of extreme left groups to spark a hunger uprising" and about "massive spontaneous uprisings [that] could occur." A provocateur detailed the role of revolutionary activists in spurring and leading the disturbances, which he then characterized as spontaneous, unprepared, and arising "exclusively on the basis of the supply crisis.” Just prior to 23 February, the police described the Petrograd SRs as expecting and preparing for revolutionary events, the exact occasion of which however they did not "presume" to predict but which they would join when appropriate. Likewise, an array of socialist commentators undiscriminatingly combined formulations of spontaneity and surprise with those of expectations, plans, and actions. Eyewitnesses sought appropriate language to encompass complex 
realities. All knew that the revolutionaries lacked the wherewithal to launch a revolution on demand but that they could and did urge strikes and demonstrations, link them to wartime hardships and shortages, and, if matters turned out propitiously, respond with heightened rhetoric and efficacious actions. Contemporaries did not starkly counterpose spontaneity to organized socialist involvement. The language of spontaneity reflected awareness of contingency, which did not diminish awareness of purposeful promotion and intervention. Once the contingent pieces of the puzzle, not without promotion (planning and urging), fell into place (by fortuitous circumstance), intervention became decisive. Tsarist, socialist, and popular observers all visualized the likely shape of the assembled puzzle and knew the pieces; the police endlessly scrambled the pieces while the revolutionaries desperately strove to arrange them. Ultimate success (failure) lay with the popular elements, a major part of the pieces, who also did not act in an informational, political, and volitional vacuum. Abandoning metaphor, by early 1917 all quarters had devoted endless prior attention to the Russian revolution and its constituent elements. Every conceivable happenstance had been mulled over so that even contingency was not entirely spontaneous. Viewed in this light, the revolution becomes explicable in terms of the full array of existing evidence about it.

Some have argued that Chamberlin's comments about Russia's February Revolution drew a contrast between the February Revolution as democratic event and the October Revolution as one-party coup. Perhaps so, but the specific wording Chamberlin employed ("the most leaderless, spontaneous revolution of all times") has led historians astray. How many of the world's great revolutions have had an advance plan worked out by a known group of people for specific times? Did Russia's February Revolution really have less previous thought, work, conscious planning, organization and leadership than the French, American, and most other revolutions? An even casual glance at recent historiography of the English and French revolutions will disabuse one of the notion of their planned orderly progress. Contingency wove its unpredictable thread through all of them, no more in Russia's February Revolution than in others. About revolutions, almost thirty years ago Lawrence Stone noted the subtle interaction of long- and short-term structural factors, such as alienation of intellectuals, ineptitude of governing elites, economic hardships, and lost wars, all of which (as the process moves from "structure to conjuncture") eventually produce the emerging counterconsensuses and leaders of the actual revolution, with its precipitants and triggers. ${ }^{75}$ Research of ensuing decades has not dealt kindly with attempts to conceptualize revolutions neatly. Regardless, Russia's February Revolution was not markedly exceptional in its characteristics.

Why has Chamberlin's formulation retained such wide currency? Western his- 
torians of leftist tendency find his approach acceptable since Bolshevik leadership so clearly faltered during the February crisis. For liberal-oriented commentators, Chamberlin's conclusion had the attraction of emphasizing simple mass protest against tsarist incompetence, aggravated by the war, leading to the fall of tsarism and its replacement by the Western-aligned Provisional Government that aimed at constitutional rule. Mass revolution brought about by joint socialist action, in which the Bolsheviks played but a minor role, occured to no one. It had neither theoretical nor historiographical underpinnings. After all, histories have misleadingly portrayed the post-1905 socialist movement, with the partial exception of the Bolsheviks, as stymied, virtually moribund, and prone to reformism.

Memoirists too helped "reconstruct" events. After the February overthrow, the right socialists entered an alliance with the liberals in constructing, supporting, and later staffing the Provisional Government and were intent on not offending their new allies. At least for public consumption, during 1917 they minimized, indeed observed scrupulous silence about, their own recent role. Just a few months later, after "their" revolution went seriously awry, with alacrity they interred the record of their earlier activities. The Kerensky of his emigre writings and speeches was a vastly different person from the revolutionary tribune he had been. He and others quietly reinvented their own histories. Within the Soviet Union, only two choices existed: remain silent or provide versions consonant with imposed requirements. Most left socialists remained in Soviet Russia. Those who emigrated also found themselves in an awkward position. Their parties, persecuted at home, had no status abroad. Further, the story they might have told was consumed in the fierce conflagration of pro- and anti-Communist debates. After all, Russia's revolution quickly became one of the century's ideologically defining events, incarcerated lock and key in one or another competing political narrative. What remained to be said that anyone would listen to about the nature of the February Revolution or the movement that had led to it? 


\section{Notes}

1. William H. Chamberlin, The Russian Revolution, 2 vols. (New York, 1965), 1: 73.

2. Michael Melancon, The Socialist-Revolutionaries and the Russian Anti-War Movement, 1914-1917 (Columbus, Ohio, 1990).

3. I would like to thank Professors Rex Wade, William Chase, and the two anonymous readers for suggestions that improved the argumentation of this study.

4. The most useful general studies of the February Revolution are those of Hasegawa, Burdzhalov, Leiberov, Pearson, and Katkov, all mentioned below, and Allan Wildman, The End of the Russian Imperial Army (Princeton, N.J., 1980).

5. The theme of left bloc cooperation receives attention in M. Melancon, “'Marching Together!’: Left Bloc Activities in the Russian Revolutionary Movement, 1900 to February 1917,” Slavic Review 49, no. 2 (Summer 1990): 239-52, and in Melancon, SRs and the Russian Anti-War Movement.

6. J. D. White, The Russian Revolution, 1917-1921: A Short History (London, 1994), 66; D. A. Longley, "Iakovlev's Question, or the Historiography of the Problem of Spontaneity and Leadership in the Russian Revolution of February 1917,” in Revolution in Russia: Reassessments of 1917, ed. by E. R. Frankel, Jonathan Frankel, and Baruch Knei-Paz (Cambridge, England, 1992), 365-87.

7. S. V. Shestakov, Istoriografiia deiatel'nosti bol'shevitskoi partii v period pervoi mirovoi voiny i fevral'skoi revoliutsii (Moscow, 1977), contains an exhaustive listing.

8. E. N. Burdzhalov, “O taktike Bol’shevikov v marte-aprele 1917 g.,” Voprosy istorii (1956); and his Vtoriaia russkaia revoliutsiia, 2 vols. (Moscow, 1967). See also Oktiabr'skoe vooruzhennoe vosstanie, 2 vols. (Leningrad, 1967), 1: 9-99 passim; I. P. Leiberov, Na shturm samoderzhavia: Petrogradskii proletariat v gody pervoi mirovoi voiny i fevral'skoi revoliutsii (iiul' 1914 g.-mart $1917 \mathrm{~g}$. (Moscow, 1979).

9. G. Katkov, Russia 1917: The February Revolution (New York, 1967).

10. Tsuyoshi Hasegawa, The February Revolution: Petrograd 1917 (Seattle, Wash., 1981); White, Russian Revolution, 66-70.

11. Sheila Fitzpatrick, The Russian Revolution (New York, 1982), 34, 38.

12. Richard Pipes, The Russian Revolution (New York, 1991), 273-78. Pipes characterizes this as an "Okhrana report" as though it were drawn up by that agency, whereas the document in question was handed in by Shurkanov, a Bolshevik provocateur. 
13. Ronald Grigor Suny, The Soviet Experiment: Russia, the USSR, and the Successor States (New York, 1998), 36-38. After firing on the crowds, units of the Pavlovskii Regiment returned to their barracks and mutinied but were subdued by the nearby Preobrazhenskii Guards. The next morning the Volynskii Regiment mutinied and joined the crowds.

14. Christopher Read, From Tsar to Soviets: The Russian People and Their Revolution, 1917-1921 (New York, 1996), 43.

15. S. Mstislavskii, Five Days Which Transformed Russia (Bloomington, Ind., 1988), 23; Delo naroda, no. 1 (5 March 1917); V. Kairurov, “Shest’ dnei revoliutskii,” Proletarskaia, no. 1 (1923): 157-58; N. Sukhanov, Zapiski o revoliutsii, 7 vols. (Berlin, Moscow, Petersburg, 1922), 1:16; O. Ermanskii, Iz perezhitogo, 1887-1921 gg. (Moscow and Leningrad, 1927), 140.

16. Kaiurov, “Shest’ dnei,” 158; Ermanskii, Iz perezhitogo, 138-39.

17. N. Sukhanov, The Russian Revolution 1917: A Personal Record, ed., abr., and tr. Joel Carmichael (Princeton, N.J., 1984), 3; L. Haimson, The Making of Three Revolutionaries: Voices from the Menshevik Past (New York and Paris, 1987), 390; A. Shliapnikov, Kanun semnadtsatogo goda (Moscow and Petrograd, 1923), 294. In an article that, like Mstislavskii's book, was originally published in the Soviet Union, the Left Centrist SR Sviatitskii wrote about the all-socialist group that "none of them imagined the nearness of the revolutionary outburst" (N. Sviatitskii, “Voina i predfevral’e,” Katorga i ssylka, no. 75 [1931]: 50).

18. For references to published sources quoted in this section, see Melancon, SRs and the Russian Anti-War Movement, 216, 219-21, 223. Henceforth all references to Melancon, SRs and the Russian Anti-War Movement are to published sources in that study.

19. L. M. Shalaginova, "Esery-internatsionalisty v gody pervoi mirovoi voiny,” in Pervaia mirovaia voina ed. A. L. Sidorov, (Moscow, 1968), 330-34; Melancon, SRs and the Russian Anti-War Movement, 222.

20. Melancon, SRs and the Russian Anti-War Movement, 196-97.

21. Ibid., 223.

22. Ibid., 193-94, 197, 199, 214, 222-23.

23. Read, From Tsar to Soviet, 43; Tsuyoshi Hasegawa, “The February Revolution,” in Critical Companion to the Russian Revolution, 1914-1921, ed. Edward Acton, Vladimir Cherniaev, and William Rosenberg (London, 1997), 48-61., 479-500.

24. Gosudarstvennyi Arkhiv Rossiiskoi Federatsii (henceforth GARF), Departament politsii, Osobyi otdel (DPOO), f. 102, 5 ch.57, l.174.

25. Ibid., ll.174-75. 
26. B. Dvinov, "Pervaia mirovaia voina i rossiiskaia sotsial-demokratiia,” University Project on the History of the Menshevik Movement, no. 10 (1962): 139; M. Rafes, "Moi vospominaniia," Byloe, no.19 (1922): 179-80; Melancon, SRs and the Russian Anti-War Movement, 200-01, 15-16; Shalaginova, “Esery-internatsionalisty v gody pervoi mirovoi voiny,” 230-34; War-time leaflets (1914-1917), Special Collections, Gosudarstvennaia obshchestvenno-politicheskaia biblioteka, Moscow; GARF, POO, f. 111, op.5, d. 658, 1. 4.

27. R. Pearson, The Russian Moderates and the Crisis of Tsarism, 1914-1917 (New York, 1977), 115-39.

28. GARF, DP OO, f. 102, op. 246, d. 9, ll. 1-2.

29. GARF, DP OO, f. 111, op. 5, d. 658, 1. 1.

30. GARF, DP OO, f. 102, op. 246, d. 9, 1. 22; Melancon, SRs and the Russian Anti-War Movement, 121-33.

31. This and numerous other SR, SD, and anarchist leaflets are in the special collections of the Gosudarstvennaia obshchestvenno-politicheskaia biblioteka, Moscow.

32. GARF, DP OO, f. 102, op. 247, 9 ch.1, ll. 1-13; Otkliki zhizni, nos.11-12 (3 December 1916); Melancon, SRs and the Russian Anti-War Movement, 145.

33. GARF, POO, f. 111, op. 5, d. 669, 1. 71.

34. For example, on 16 February ten anarchists and five SRs were arrested in the capital; ibid., d. 659, 1. 14. On the evening of 25 February, Minister of the Interior Protopopov personally presided over the arrest of over a hundred revolutionaries of all parties.

35. GARF, DP OO, f. 171, op. 247, d. 171, ll. 17-21; DP OO, f. 102, op. 247, d. 171, ll. 30-34, 56-61, 95-98; POO, f. 111, op. 5, d. 669a, 1l. 14, 31.

36. GARF, POO, f. 111, on. 5, g. 658, 1.10 .

37. GARF, POO, f. 111, op. 5, d. 669, 1. 230; d. 669a, 1. 38; Melancon, SRs and the Russian Anti-War Movement, 214.

38. Material in the following four paragraphs is from Rossiiskii tsentr khraneniia istoricheskikh dokumentov noveishei istorii (RTsKhIDNI), f. 70 (Istpart), op. 3, d. 378, ll. 1-2; d. 559, ll. 1-13.

39. See Zhurnal, 10-14 February 1917, stamped “Top Secrect” in GARF, f. 111, op. 5, d. 669, l. 190; f. 102, op. 247, d. 171, ll. 108-10; Melancon, SRs and the Russian Anti-War Movement, 203-06.

40. I. I. Mil’chik, “Fevral’skie gni na Vyborgskoi storone,” Leningradskaia pravda, no. 59 (28 February 1927). 
41. RTsKhIDNI, f. 70, op. 3, d. 378, 1l. 2-5; d. 559, ll. 14-18; d. 594, 1l. 1-2; d. 623, ll. 1-10.

42. Melancon, SRs and the Russian Anti-War Movement, 232. Chugurin, a Bolshevik member of the Vyborg committee, recalled the committee's desire to "keep the workers' mood on the boil until 1 May” (quoted in White, Russian Revolution, 67, n. 9).

43. Longley, “Iakovlev's Question”, 365-87. In thus altering emphases, Longley hoped to delimit the role of the Bolsheviks, who, in his and other historians' views, dominated the Vyborg District factories. Since this Bolshevik predominance is imaginary, nothing is gained by the shift from 23 to 21-22 February and from the Vyborg to the Narva districts. All participants saw the twenty-third as decisive.

44. GARF, POO, f. 111, op. 5, d. 669, 1l. 89-154, 270-74, 280, 294, 316; d. 673, 1. 8.

45. RTsKhIDNI, f. 70, op. 3, d. 559, l. 18; d. 563, l. 4; I. Markov, “Kak proizoshla revoliutsiia,” Volia Rossii (Prague), no. 3 (1927): 67.

46. Ermanskii, Iz perezhitogo, 138-39; I. Iurenev, “Mezhraionka,” Proletarskaia revoliutsiia, no.1 (1924): 137-38; Melancon, SRs and the Russian Anti-War Movement, 230-34.

47. Melancon, SRs and the Anti-War Movement, 261; "Fevral'skaia revoliutsiia i okhrannoe otdelenie,” Byloe, no. 1 (1918): 169-71.

48. See Michael Melancon, "Who Wrote What and When?: The Proclamations of the February Revolution,” Soviet Studies, no. 3 (July 1988): 480-84.

49. GARF, POO, f. 111, op. 5, d. 669, ll. 172, 176-77, 319; RTsKhIDNI, f. 70, op. 3, d. 559, ll.18-19.

50. GARF, POO, f. 111, op. 5, d. 669, ll. 66, 132-34, 154-55, 320-21, 324-25; Milchik, "Fevral'skie dni."

51. Milchik, “Fevral’skie gni,” ll.

52. GARF, DP OO, f. 102, op. 247, d. 171, ll. 133-34; POO, f. 111, op. 5, d. 669, ll. 155-56, 338-42, 347, 350; RTsKhIDNI, f. 70, op. 3, d. 559, l. 20; P. P. Aleksandrov, Za Narvskoi zastavoi (Leningrad, 1963), 125-26; V. M. Kruchkovskaia, Tsentral'naia Gorodskaia Duma v $1917 \mathrm{~g}$. (Leningrad, 1986), 19.

53. “V Petrograde nakanune fevral’skoi revoliutsii,” Krasnaia letopis’, no. 22 (1927): 47.

54. GARF, POO, f. 111, op. 5, d. 669, 1. 356; “Fevral’skaia revoliutsiia i okhrannoe otdelenie,” 172.

55. Melancon, SRs and the Russian Anti-War Movement, 256-64; A. Kerensky, The Crucifixion of Liberty (New York, 1934), chap. 7; A. Blok, “Poslednie dni tsarizma,” Byloe, no. 15 (1919): 28. 
56. Melancon, SRs and the Russian Anti-War Movement, 266.

57. Melancon, SRs and the Russian Anti-War Movement, chap. 7; "Who Wrote What," 479-500; and "International Women's Day, the Finland Station Proclamation and the February Revolution: A Reply to Longley and White,” Soviet Studies, no. 3 (July 1990): 583-89.

58. The history of these leaflets with texts and lengthy quotations is found in Melancon, "Who Wrote What," 479-500.

59. “V Petrograde nakanune,” 47; “Fevral’skaia revoliutsiia i okhrannoe otdelenie,” 173-74.

60. E. D. Chermenskii, “Nachalo vtoroi rossiiskoi revoliutsii,” Istoriia SSSR, no.1 (Jan.-Feb. 1987): 99.

61. RTsKhIDNI, f. 70, op. 3, d. 565, 1. 1: (A. A. Dumber, "Vospominaniia o fevral'skoi-oktiabr'skoi revoliutsii,”); d. 563, 1. 5 (I. Gavrilov, “Moi vospominaniia o 1917 gode.”)

62 . I. P. Leiberov, Na shturm samoderzhaviia: Petrogradskii proletariat v gody pervoi mirovoi voiny i fevral'skoi revoliutsii (iiul' 1914-mart 1917 g. (Moscow, 1979), 233, 239; Sukhanov, Zapiski o revoliutsii, 1:83; Melancon, SRs and the Russian Anti-War Movement, 258-59; K. F. Shatsillo, "Proletariat v fevral'skoi revoliutsii,” Istoriia SSSR, no. 5 (1977): 93; L. M. Gavrilov, “Russkaia armiia nakanune fevral’skoi revoliutsii,” Istoricheskie zapiski, no. 114 (1986): 67; Petrogradskii sovet rabochikh i soldatskikh deputatov v 1917 godu. Protokoly, stenogramy . . . obshchikh sobranii, sobranii sektsii, zasedanii Ispol'nitel'novo komiteta i fraktsii, 27 fevralia-25 oktiabria 1917 goda, 5 vols. (St. Petersburg, 1993), 1:38.

63. I. Lukash, Litovtsy, Pavlovtsy, Preobrazhentsy, Volyntsy, all four of which have the following publication data: Petrograd: Vremennyi komitet Gos. Dumy, 1917; T. Kirpichnikov, "Vosstanie l. gv. Volynskogo polka v fevrale 1917 g.,” Byloe, nos. 5-6 (Nov.-Dec. 1917): 5-16. Perhaps the publication of these particular items by liberals and extremely moderate socialists, who already in 1917 had no stake in emphasizing left socialist activities, accounts for their uncanny depoliticization. “Dnevnik soldata na Vyborgskoi storone,” Pravda, no. 5 (10 March 1917), simply says that when news came that some units had fired on demonstrators on 26 February conversations began among "the more reliable comrades about how to unite with the revolutionaries." Presumably the "more reliable comrades” were socialist party members. V. Baranovskaia, SoldatyPavlovtsy (Leningrad: Lenizdat, 1968), 35-42, follows Lukash’s account closely, thus repeating the version "without parties." See also later memoir accounts of D. N. Glinkin in RTsKhIDNI, f. 70, op. 3, d. 564, l. 1, and T. Kirpichnikov, “Vosstanie Volynskokogo polka,” Ogonek, no. 11 (13 March 1927). My hypothesis of a minor Bolshevik role in the face of considerable involvement of other parties, especially the SRs, would, if correct, explain the Bolshevik-Soviet reticence on the matter of socialist activities. Had the Bolsheviks been involved, the memoirists would have loudly broadcast this; after all, undaunted by the mere lack of substantiation, much subsequent Soviet-era historiography proclaimed Bolshevik leadership anyway.

64. Shatsillo, “Proletariat v fevral'skoi revoliutsii,” 95; Chermenskii, “Nachalo Vtoroi Rossiiskoi 
Revoliutsii,” 96. Among identifiable leaders of the Second Marines, M. Sokolov evidently had no party ties, whereas Skobeiko and Khomiakov were SRs.

65. RTsKhIDNI, f. 70, op. 3, d. 618, 1. 1 .

66. F. Sorokin, Gvardeiskii ekipazh v fevral'skie dni i 1917 g. (Moscow, 1932), 18-25.

67. V. Iu. Cherniaev, “Oranienbaumskoe vosstanie v fevrale 1917 g.,” Istoricheskie zapiski, no. 114 (1986): 262-66; I. S. Rozental', “Garnizony prigorodov Petrograda v Fevral'skoi revoliutsii,” in Revoliutsionnoe dvizhenie v Russkoi armii 1917 goda. Sbornik statei (Moscow, 1981), 156-58; Sorokin, Gvardeiskii ekipazh, 45-47.

68. F. F. Raskol’nikov, Kronshtadt i Piter v 1917 godu, 2nd. ed. (Moscow, 1990), 21.

69. V. Bazarov, “Pervye shagi russkoi revoliutsii,” Letopis’, nos. 2-4 (February, March, April 1917): 377-80.

70. Sukhanov, The Russian Revolution, 5-24.

71. Ibid., 39.

72. N. I. Iordanskii, “Voennoe vosstanie 27 Fevralia,” Molodaia gvardiia, no. 2 (1927). Quotations in this and the following two paragraphs are from pp. 162-72.

73. In a very recent account, Hasegawa casts doubt upon the rapid and easy progress of the soldiers' revolt, noting that not all units were easily subverted and that some offered armed resistance to attempts to bring them over; he also emphasizes their allegedly chaotic behavior after joining the uprising (Hasegawa, "February Revolution," 53-54). On the previous page of the same study, however, he provides a very different view that merits quotation: "Early on the morning of 27 February the soldiers of the Volynskii Regiment revolted. The mutiny quickly spread to the neighboring military units. . . . On the other side of the Neva in the working-class Vyborg District, a second armed revolt was taking place, this one led by determined worker activists. In early afternoon the two revolts were linked. After establishing the Tauride Palace as its centre, the insurrection spread to all parts of the city" and so forth. Attention in this essay focuses not on those soldiers who at first resisted or who, when they joined the mutiny, acted aimlessly, but on the far more remarkable phenomena described by Hasegawa himself. These latter phenomena are better explained by the putative presence of socialist leadership within the units than by some accidental or spontaneous theory.

74. Kerensky’s papers, including thousands of such letters, are in GARF, f. 1807, d. 453.

75. Lawrence Stone, The Crises of the English Revolution, 1529-1642 (London, 1972), 3-25. 
Center for Russian \& East European Studies

University Center for International Studies

University of Pittsburgh

4400 W. W. Posvar Hall

230 South Bouquet Street

Pittsburgh, Pennsylvania 15260

(412) 648-7407

William Chase, Bob Donnorummo, Ronald Linden, Co-Editors Eileen O’Malley, Managing Editor 